\title{
FINANCIAL SUPPORT OF CHILDREN AND THE END OF WELFARE AS WE KNOW IT
}

\author{
Stephen D. Sugarman*
}

\section{INTRODUCTION}

$\mathrm{W}$ HO should financially support America's children? Our nation is badly divided over which fundamental principles we should use to answer this question. In the discussion that follows, I set forth what I understand to be competing conservative and liberal visions of individual and collective obligations to provide for children. I then describe the proper role of government implied by both perspectives and the shortfalls of our current policies as judged by each. Viewed in this way, it is unsurprising that today's child support regime appears to satisfy no one. Next I explore whether a new consensus across ideological lines might be forged. I examine the objection to long-term dependency, the call for required work, the clanor for abandoning a federal role, and the threats to take children away from their parents. Finding little appeahing middle ground in these ideas, I finally consider whether some sort of "child support assurance" scheme might garner widespread support; in particular, I propose an expanded role for our Social Security system.

\section{A Conservative Vision}

The conservative view ${ }^{1} I$ have in mind rests on the principle that although having and raising a child can be a wonderful thing, moral obligations attach to that decision; until one can financially afford to provide adequate food, shelter, clothing and the like for a child, it is morally irresponsible to have one. To be financially ready to raise children typically requires job security or clear employment

* Agnes Roddy Robb Professor of Law, University of California; Berkeley (Boalt Hall).

1 Of course, conservatives-and certainly many Republicans-have different views. I mean to present a stylized synthesis of what I see as the "conservative" perspective. See generally William J. Bennett, Reflections on the Moynihan Report, 6 Am. Enterprise, Jan./ Feb. 1995, at 28 (offering a conservative perspective on the Moynihan Report 30 years after its publication). 
options and some savings. Although it is not always essential for both parents to have reliable earnings opportunities, if a woman is not readily able to support her child without financial assistance, she needs to be especially careful. In those circumstances, it is morally reckless for her to bear a child unless she is confident that the child's father has made, and can be counted on to honor, a genuine financial commitment to the child. Because marriage is seen as a way of maximizing that prospect, choosing to become a single parent (or deciding to become pregnant when one's marriage is on the rocks) is very often morally culpable behavior.

The morally responsible husband honors his financial obligation to his child even if there is a breakdown in his marital relationship-perhaps remaining with his wife for the sake of the child, but in any event dutifully paying child support even if he becomes the noncustodial parent. ${ }^{2}$ Men who knowingly or carelessly impregnate women to whom they are not married are usually morally irresponsible for doing so and in any case should take responsibility for the resultant child's financial needs regardless of their actual intentions at the time the sexual relation occurs.

Just as married parents ought not have additional children they cannot afford, so too it is morally blameworthy for a father who is living apart from his former wife and children to take on additional financial responsibilities to new children if this interferes with his ability to support his existing children. On the other hand, when a father or mother can afford it, it is morally praiseworthy for them to support other people's children by becoming a stepparent or an adopting parent.

Responsible parents realize that a variety of risks threaten the future income necessary to support their children, and so they have a duty to take precautions against those risks to the extent feasible. This implies, for example, that most parents have a moral responsibility to carry life and disability insurance. When unemployment is the alternative, it also means staying with a job, even if it is emotionally and physically taxing. Often a parent will be morally obhiged to accept the security of steady employment, even if he or

2 Here and elsewhere throughout this Article, I put men and women in their stereotypical roles, recognizing, of course, that these stereotypes are not always accurate. 
she would have otherwise preferred to take a chance with something speculative.

Ordinarily, the risk of insecurity also creates a moral duty to maintain good relations with family meinbers who might be relied on to come voluntarily to the aid of one's child should an unavoidable crisis occur. Indeed, parents have an obligation to coine to the aid of their own adult children if they need assistance in providing for the grandchildren.

In short, having a child should not be considered a right, but rather a responsibility. Government's role, if any, should be to encourage responsible behavior, certainly not to undercut it. If, as a result, some poor people are discouraged from having children, so be it. Certainly in today's econorny and political setting, it is not essential for everyone to have children; our society no longer needs masses of bodies to serve as unskilled laborers or soldiers. Therefore, it is better that children who would otherwise lead an impoverished life are not born. Moreover, a norm emphasizing financial responsibility might encourage harder work from those who want to have children, preventing their poverty as well.

\section{A LibERAL Vision}

The contrasting hiberal vision I have in mind rests on very different primciples. ${ }^{3}$ First, because having and raising a child can be a wonderful thing and an expression of one's identity, everyone in our society who wants to do it should be enabled to do so-at least if they are emotionally mature enough. This implies a collective moral obligation to aid those would-be parents among us who would otherwise be too poor to support their children on their own. ${ }^{4}$ Second, this vision recognizes from the outset that, short of mass sterilization, most women will bear children. It further holds

3 Again, this perspective is not meant to capture the views of all liberals, Democrats, leftists and so forth. Rather, it is intended as a synthesis of the predominant countervision to the conservative view earlier presented. For a somewhat different characterization of the liberal outlook, see Larry Catã Backer, Welfare Reform at the Limit: The Futility of "Ending Welfare As We Know It," 30 Harv. C.R.-C.L. L. Rev. 339 (1995).

4 As two liberal lawyers recently argued in response to proposed welfare cuts, "[t]lue purpose of the ... exclusion is to deny subsistence welfare benefits to woinen who exercise the riglit to choose childbearing while they're poor." But there should be no "means test for reproductive freedom." Deborah Lewis \& Martlia Davis, Correspondence, New Republic, Mar. 13, 1995, at 6 (letter to editor from the Legislative Counsel of the American 
that the resulting innocent children are entitled to a decent life regardless of what one might think of the morality of their parents. Moreover, although liberals agree that parents have a duty to support their children when they are financially able to do so, they are not committed to the belief that it is routinely better for children to be raised in a traditional family. For example, a woman should be enabled to raise her children without marrying a man if that is her preference; likewise, both same-sex couples and unmarried couples are quite acceptable as "parents."

Liberals, too, praise those who take on responsibility for other people's children, but in their vision, a man's first children have no greater claim to support from their father than do later-acquired step-children or newborn children with a different mother. In short, earlier children have no more priority than do older siblings within a traditional family.

Liberals believe needy children are not to be pnmished for the sins of their parents. Thus, even if the mother engages in morally questionable conduct, such conduct should not to lead to any loss of the household's welfare benefit. Of course, if the conduct is so bad as to render the mother unfit, the children must be removed from her custody and made wards of the state. Perhaps it is unwise for a poor woman already on welfare to have (or risk having) more children, but this decision is best left to the mother, aided by government-provided education and voluntary birth control programs, but free froin threats of financial penalties that, if imposed, would simply punish the newborn and his or her sibling(s).

The 1968 U.S. Suprene Court's decision in King v. Smith ${ }^{5}$ well reflects this liberal vision. In King, the Supreme Court considered for the first time a case imvolving welfare, that is, Aid to Families with Dependent Children ("AFDC"). There the plaintiffs successfully invoked congressional enactments and the Supreinacy Clause to invalidate inconsistent state law. In its opimion, the Court empliasized that AFDC exists primarily to provide income to poor children who have been deprived of financial support from their absent breadwinner fathers. ${ }^{6}$ AFDC's cash grants therefore permit

Civil Liberties Union and the Senior Staff Attorney for the NOW Legal Defense and Education Fund).

5392 U.S. 309 (1968).

6 Id. at 313. 
single mothers to raise their children at home rather than, for example, forcing mothers to put them up for adoption or doubling up with relatives. Since these women were not expected to seek regular employment in the paid labor market (at least in 1968), it was all right, when necessary, for them to rely on AFDC until their children grew up and left home.

The Alabama laws at issue in King reflected a wholly different outlook from the liberal vision and were accordingly condemned by the Court. Alabama's statute cut off AFDC to a poor, unmarried mother if she had regular sexual relations with a inan who was not the father of her children. ${ }^{7}$ Thus, a mother would be excluded from the AFDC program even though her lover liad no legal duty to provide child support, never actually did so, and did not even live with her. In effect, Alabama asserted that the price of sleeping witl a man was having to look to him instead of the state for financial support.

Its effort to defend the AFDC statute on moral grounds liaving been rejected, Alabama next attempted to support its policy with two other conservative arguments based on mcentives. First, by discouraging extramarital sex, the Alabama rule would also discourage illegitimate births and the resulting higher state welfare burdens. Second, by treating those who slept (and lived) together just like those who were married, the Alabama rule would not discourage marriage. Both claims were rejected outright by the Court. $^{8}$

\section{The Proper Role for Government In the CONSERVATIVE VISION}

Is there any role for government in the conservative vision I have set forth? Several years ago, Roger McIntire imagined that government could put a birth control substance he called "lock" in the water supply, making available its antidote (called "unlock") only to certain people. ${ }^{9}$ Although McIntire liad in mind requiring people who wanted "unlock" to demonstrate that they were likely

7 Id. at 313-14 (citing Alabama Manual for Administration of Public Assistance, pt.I, cl.II, § VI).

8 Id. at 320-33.

9 Roger W. McIntire, Parenthood Training or Mandatory Birth Control: Take Your Choice, 7 Psychol. Today, Oct. 1973, at 34, 38. See also Hugh Lafollette, Licensing Parents, 
to be effective parents (by having taken parenting education), ${ }^{10}$ in our context perhaps "unlock". should be withheld until prospective parents can deinonstrate financial reliability.

Although this hypothetical option might be attractive in soine conservative quarters, in the end most conservatives would probably oppose it, fearing that government control of "unlock" might lead to abuses that would ultimately threaten the reproductive freedom of even responsible individuals. ${ }^{11}$ Other scenarios designed to promote financially reliable parenting might not be so objectionable, however, such as the routine admimistration of "lock" at birth if, in turn, it automatically wore off on one's eighteenth (or twenty-first?) birthday. ${ }^{12}$ Recent years have actually seen the development of a contemporary approximation of "lock" in the form of Norplant, a long-term but reversible contraceptive that we inay assume for our purposes requires but a single application. Even so, while certain liberals have expressed concern about the selective imposition of Norplant on soine poor women, ${ }^{13}$ no one seems to be seriously proposing that government require its universal application, say, to teenagers.

A less dramatic proposal, endorsed for exainple by the late Christopher Lasch, suggests that instead of today's easy divorce laws, the state should prevent parents froin ending their marriage so long as they have minor children in their care. ${ }^{14}$ Under this proposal, the state would license matrimony in a far more restrictive manner than it does now-at least partly to benefit children financially. Although it may well capture the conservative's ethical aspirations in general, this recommendation, as a firm legal proposition, is problematic given the unfairness of its application to

9 Phil. \& Pub. Aff. 182 (1980) (suggesting that parents should be licensed as a possible social and regulatory response to safeguard children and to preserve other social interests).

10 See McIntire, supra note 9, at 39.

11 In other words, broader conservative principles would trump the use of this mechanism to promote conservative objectives in this specific area.

12 This approach, however, would draw objections from those who would fear that "lock" would promote increased teen promiscuity.

13 See, e.g., Catherine Albiston, The Social Meaning of the Norplant Condition: Constitutional Considerations of Race, Class, and Gender, 9 Berkeley Women's L.J. 9 (1994).

14 Benjamin Barber, Mary Ann Glendon, Dan Kemmis, Christopher Lasch \& Christopher D. Stone, Who Owes What to Whom? Drafting a Constitutional Bill of Duties, Harpers, Feb. 1991, at 43, 47-48. 
cases of physical abuse of the divorce-seeking spouse (or child) and the senselessness of its apphication to cases of abandonment. In short, how can we morally prevent a mother who is being abused by her husband froin getting away from him and marrying another man if she wishes to do so? And what is the point of preventing a woman from remarrying if her husband has deserted her and their children? ${ }^{15}$

These objections, of course, would not apply to a somewhat less restrictive domestic relations law that, for exainple, might bar divorce by parents with young children on grounds of mere incompatibility. Many conservatives may be tempted to support this move away from no-fault divorce-even though a couple that agreed to divorce could probably circumvent the restriction by turning incompatibility into abandonment. The key point is that this restriction would enable a spouse who had not badly misbehaved to veto a divorce sought by the other spouse. Nevertheless, it would not prevent that other spouse from leaving and taking up with a new partner (assuming, of course, that courts would not issue injunctions ordering such spouses to live at home). Essentially, the law would only preclude a spouse's remarriage. Although this restriction would probably have little practical effect in most communities these days, in those places where living together outside of marriage is still stigmatized, conservatives might find appealing the potentially prophylactic effect of limiting divorce in this way. ${ }^{16}$

If imposing a more restrictive divorce law is of limited proimise as a way to assure the financial support of children, perhaps aggressively enforcing child support obligations imposed on those not livmg with their children (i.e., typically noncustodial fathers) would

15 For a critique of penalties imposed on those seeking divorce, see Linda Lacey, Mandatory Marriage "For the Sake of the Children": A Feminist Reply to Elizabeth Scott, 66 Tul. L. Rev. 1435, 1453-61 (1992); Stephen D. Sugarman, "Family Law for the Next Century": Background and Overview of the Conference, 27 Fam. L.Q. 175, 182-83 (1993).

16 Yet another proposal is to impose a delay on divorce when minor children are involved, perhaps with exceptions made in cases of domestic violence. See generally Elizabeth S. Scott, Rational Decisionmaking About Marriage and Divorce, 76 Va. L. Rev. 9 (1990) (exploring precommitment theory as a way to evaluate and reform divorce laws). Although the goal is to encourage reconciliation and to discourage hasty action, it is unclear whether this rule would actually accomplish anything more than delaying remarriage to a new partner. 
be more appealing. In fact, conservatives seem to have joined forces in the contemporary political scene with feminists who bemoan the woeful financial position of mothers who usually wind up with the children, but all too often lack the money to support them from absent fathers. ${ }^{17}$

Conservative unease here is primarily an issue of federalism. If tough child support enforcement is needed, who should provide it - the national government or the states? Simce family law is traditionally thought of as the preserve of local government, it has been at least somewhat surprising to see substantial conservative support for a strong federal role in child support enforcement beyond that already necessary where the parents live in different states. ${ }^{18}$ In recent years, conservative-backed federal reforms have included demands that states adopt both uniform and fairly stringent levels of child support obligations. ${ }^{19}$

Federalism concerns aside, adopting a strong child support regime would seem to be an appropriate role for government from the conservative viewpoint, even if it means jailing so-called deadbeat dads who willfully default on their child care obligations (unless it can be shown, as many liave claimed, that this is counterproductive in practice, despite its theoretical benefit as a deterrent). ${ }^{20}$

The imposition of private support obligations beyond parentsto grandparents, for example - is yet another possible role for the state under the conservative vision. ${ }^{21}$ On the other hand, placing legal support obligations on live-ins is more perplexing as a con-

17 See Marsha Garrison, Child Support and Children's Poverty, 28 Fam. L.Q. 475 (1994) (reviewing Andrea H. Beller \& John W. Graham, Small Change: The Economics of Child Support (1993) and Donald J. Hernandez, America's Children: Resources from Family, Government and the Economy (1993)).

18 See New York Newsday Roundtable With William Julius Wilson and Lawrence Mead; Whose Ideas Will Save the Underclass?, Newsday, Dec. 19, 1988, at 45 (discussing a "liberal/conservative consensus" that accepts a federal solution to resolve child support evasion, e.g., the Family Support Act of 1988).

19 Family Support Act of 1988, Pub. L. No. 100-485, 102 Stat. 2343 (codified as amended in scattered sections of 42 U.S.C.); Child Support Enforcement Amendments of 1984, Pub. L. No. 98-378, 98 Stat. 1305 (codified as amended in scattered sections of 42 U.S.C.).

20 See, e.g., David L. Chambers, Making Fathers Pay: The Enforcement of Child Support (1979).

21 See Robert J. Levy, Rights and Responsibilities for Extended Family Members?, 27 Fam. L.Q. 191, 205 (1993). 
servative proposition. Whereas marriage, the more desired relationship from the conservative perspective, would no longer be financially disadvantageous to the would-be stepfather, such a rule might discourage a live-in from joining the household in the first place-thereby denying the child the practical reality. of some financial support from the live-in parent, despite the absence of a formal duty to do so.22

Not wanting to discourage men from marrying women who already have children, the conservative vision may also find problematic the notion that once one has taken on the actual financial support of a stepchild, a duty should attach to continue that support even after the relationship with the child's parent has ended. ${ }^{23}$ On the other hand, refusing to reduce the support obligation to one's children after divorce, even after one has become a stepparent or new parent, fits comfortably with the conservative goal of discouraging men from assuming new child support obligations unless they can afford to provide for their existing children as well. ${ }^{24}$

In summary, for conservatives, the central function of the state with respect to the financial well-being of children arises in what conventionally has been called the "private law" realm-the imposition and enforcement of bloodline-based child support obligations. I later consider more closely the conservative response when what is considered to be morally irresponsible conduct takes place anyway. ${ }^{25}$

22 See generally David L. Chambers, Stepparents, Biologic Parents, and the Law's Perceptions of "Family" after Divorce, in Divorce Reform at the Crossroads 102-09 (Stephen D. Sugarman \& Herma Hill Kay eds., 1991) (discussing financial support often provided by a stepparent, despite absence of a formal obligation to do so).

23 Levy, supra note 21 , at 204-12.

24 Here conservatives and some feminists agam may join forces. See Deborah $L$. Rhode \& Martha Minow, Reforming the Questions, Questioning the Reforms: Feminist Perspectives on Divorce Law, in Divorce Reform at the Crossroads, supra note 22, at 191, 207 (arguing that child support obligations of divorced fathers should not be altered because of new support obligations).

25 See infra notes 54-55 and accompanying text. 
IV. The Proper Role for Government in the LIBERAL VISION

Traditionally, liberals have wholeheartedly embraced the redistribution of income through taxing and spending programs in order to provide financial support to clildren. Programs offering cash aid to needy families further the two central liberal principles set forth earlier. First, a promise of financial support to parents in need enables a prospective mother to be confident she will be able to afford to raise that child. Second, the actual provision of such funds helps to provide a decent life for the child once born. Putting the second proposition differently, a central collective function of government in the liberal vision is to assure moderate, but adequate and nonstigmatizing, financial support to impoverished parents so that no children have to live in poverty. In practice, the second goal complements the first because it is usually thought best for the child to provide financial assistance in a way that keeps the child with his or lier family (so long as the custodial parents are not abusing or otherwise neglecting the child). Providing the aid in a nonstigmatizing way is better for both the parents and the child because the parents would otherwise be demeaned in the clild's eyes as well as their own.

Liberals further perceive that many parents either cannot or do not take precautions against future financial risks, which necessitates an additional role for government. For example, some people just do not understand or will not botlier to buy life and disability insurance, protection that society can efficiently provide collectively. Government can also provide otlier sorts of income security, like unemployment insurance, that are unavailable througli the private market. In short, when custodial parents become economically needy from common social or structural events such as the death of a spouse or a parent's inability to obtain a decent paying job, liberals see a need for government action.

Liberals also appreciate that, despite reasonable precautions women might take, regardless of government efforts, inany men will leave them (or never live with them) and irresponsibly fail to pay the child support that liberals generally agree that they owe. Even if a father pays what he legally owes, his support will often not yield enough cash to sustain a child adequately. This, too, implies a need for government financial support of children. 
As already noted, liberals, like conservatives, generally welcome collective efforts to assure that absent fathers fulfill their child support obligations. At least some liberals, however, seem less willing to allow biology to serve as the single criterion upon whicli to base the duty to support. Just as it would be odd to liold a sperm donor financially responsible for children conceived through artificial insemination, so too some liberals liave qualms about imposing financial duties on a man who impregnates a woman but never lives with lier or claims any interest im the child. ${ }^{26}$ This tax on what some call promiscuity seems especially questionable to liberals if the woman has access to abortion and chooses to bear the child anyway, particularly when the man liad urged lier to terminate the pregnancy. ${ }^{27}$ In any event, even absent the biological tie, once a person has taken on financial responsibility for children, and they have come to rely on that support, many hberals appear willing to impose an obligation of continuing child support on that individual. ${ }^{28}$ This issue commonly arises when a stepfather who has assumed the financial role of parent separates from the mother of his stepchildren (via divorce or her death). In this situation, some liberals might respond more favorably than conservatives to state recognition of what might be termed "de facto adoption" obligations.

In this same vem, liberals would not impose de facto parental status on men who merely liad a sexual relation with the mother and did not actually provided financial support to the child. This distinction often plays out in the AFDC context where, as in King v. Smith, conservatives have wanted to cut public assistance when a

${ }^{26}$ See, e.g., Harry D. Krause, Child Support Reassessed: Limits of Private Responsibility and the Public Interest, in Divorce Reform at the Crossroads, supra note 22, at $166,178-83$ (arguing that the level of child support owed by an absentee father should have some relation to the level of relationship he shares with his children).

27 On the other hand, hiberals would probably feel differently if the man (a) pressed the woman into sex, (b) refused himself to take precautions against pregnancy, (c) orally promised during the pregnancy to take responsibility for the child, or (d) later claimed fatherhood of the child. Since reliable proof of who did and said what may be hard to come by in these settings, practical problems in determining where real justice lies may, in the end, bring these liberals closer to conservatives in using biology as the normal indicator upon which to base the legal duty of financial support.

28 Mary Ann Mason, The Ambiguous Step-Parent: Federal Policy in Search of a New Model, 29 Fam. L.Q. (forthcoming 1995). 
man has "assumed the role of spouse" 29 merely by living with the mother, whereas liberals have insisted on cutting assistance only when the man is actually contributing financially to the household. In sum, for liberals, government has a large "public law" cash transfer role to play, along with its enforcement role regarding private child support obligations.

\section{The Problem with Government's Current Role from the Cónservative Perspective}

From the conservative perspective, existing law and policy is in many respects counterproductive. AFDC is especially unsatisfactory because it is viewed as inducing poor, single woinen to have children that they cannot afford to raise on their own in circumstances where the father cannot be counted on to provide adequate support. $^{30}$ Moreover, government financial aid to single parent families appears to both discourage marriage and encourage men not to fulfill their financial obligations. ${ }^{31}$ Finally, conservatives see AFDC as enticing people who already have children to act irresponsibly by reinaining unemployed so as to allow themselves to fall into poverty (thereby qualifying for welfare) and remain there. ${ }^{32}$ Clearly, this conservative critique assumes that people respond rather strongly to financial incentives. In this sense the conservative sees people through an economist's lens.

For those with a conservative viewpoint who believe themselves to be acting responsibly, it is especially galling to see their tax money applied to fund our current welfare system. Similarly, the failure of courts and other arms of local government to enforce absent fathers' child support obligations effectively ${ }^{33}$ is considered

29 See Lewis v. Martin, 397 U.S. 552, 554 (1970) (considering a Cahifornia law that decreased welfare payments where "an adult male person assum[ed] the role of spouse to the mother although not legally married to her") (citation omitted).

30 See generally Charles Murray, Losing Ground: American Social Policy, 1950-1980 (1984) (discussing the historical development of public opinion regarding welfare and arguing that the welfare system has encouraged irresponsible behavior).

31 Id.

32 See, e.g., Lawrence M. Mead, Beyond Entitlement: The Social Obligations of Citizenship (1986) (suggesting that welfare recipients should work as a precondition for receiving government benefits).

33 See generally Garrison, supra note 17 (reviewing two critical studies on child poverty, child support, and inadequate enforcement). 
a disgrace from the conservative perspective, especially given their belief that the imposition of financial responsibility will discourage men from acting irresponsibly in the first place.

Despite their disgust with the current system, it should not be assumed that conservatives would instead flock to support the use of public money to stimulate morally proper conduct-as might arguably occur were poor people offered a bribe to marry. ${ }^{34}$ Regardless of the result, it is morally troubling to many conservatives to pay people to do the right thing. To reemphasize the point, in the conservative vision I have presented, government's central role is to help enforce morally upright conduct with sticks, not carrots.

\section{The Problem with Government's Current Role from the Liberal Perspective}

From the liberal perspective, the abstract idea of an AFDC casi transfer program is attractive. The liberal vision rejects the claim that narrow financial incentives yield dramatic human responses when it comes to critical decisions such as laving children and getting married, believing instead that these actions are dominated by cultural, or perhaps even biological, forces. ${ }^{35}$ In short, the liberal downplays the economic vision of man as a supremely rational calculator, adopting the sociologist's or psychologist's outlook instead. Thus, the liberal believes it is in the nature of humans to make

34 Although "bridefare," a welfare experiment in which getting married is rewarded, has gained considerable attention, so far it has apparently been adopted on an experimental basis only in Wisconsin. See Tracy Thompson, Unhitched but Hardly Independent; Having No Husband Complicates Escape from Welfare, Wash. Post, May 13, 1995, at A1.

35 See, e.g., Mimi Abramovitz, Regulating the Lives of Women: Social Welfare Policy from Colonial Times to The Present (1988) (blaming the "family ethic" for women's poverty, rather than the welfare system itself); Fred Block, Richard A. Cloward, Barbara Ehrenreich \& Frances Fox Piven, The Mean Season: The Attack on the Welfare State (1987) (rebutting conservative arguments that welfare has encouraged poverty); David T. Ellwood, Poor Support: Poverty in the American Family (1988) (arguing that cultural changes, not financial incentives, have caused changing family structure); Robert Greenstein, Losing Faith in 'Losing Ground' New Republic, Mar. 25, 1985, at 12 (criticizing Murray's thesis that social programs encourage joblessness); Andrew Hacker, Getting Rough on the Poor, N.Y. Rev. of Books, Oct. 13, 1988, at 12 (arguing that restraints on federal welfare assistance will not solve the problems of poverty and single motherhood). 
mistakes, act foolishly, hold unrealistic hopes, and the like, ${ }^{36}$ rendering it unhelpful and unfair to make collective assistance turn upon mdividualized mquiries into fault as measured against the paragon of virtue to which conservatives aspire.

What is objectionable to liberals, however, is the way current welfare programs are actually designed and administered. Most importantly, because benefit levels are woefully low, AFDC today fails to permit parents to provide a decent inaterial living standard for their children, unless welfare mothers clieat and illegally obtain other incoine. ${ }^{37}$ Moreover, liberals believe AFDC is administered in a demeaming manner because of the way it is managed and the social stigma that attaches to its participants. ${ }^{38}$ Finally, AFDC (or a meaningful substitute) has been largely unavailable to two-parent families where both parents are unemployed or one is working regularly but still cannot provide for the family because of low pay. ${ }^{39}$ Improvements in the Earned Income Tax Credit, ${ }^{40}$ adopted at the outset of the Clinton presidency, appear to have substantially ameliorated this last concern. ${ }^{41}$

In contrast to AFDC, the existing approach taken by the Social Security systein with respect to certain presumptively needy children and their parents (described in nore detail below) is far more attractive to liberals. Under that program, mandatory family benefit provisions have been in place for decades to assure that widows and children of deceased workers and wives and children of disabled workers have reasonably adequate support. ${ }^{42}$ In so doing,

36 For a discussion of this idea in a different context, see Howard Latin, "Good" Warnings, Bad Products, and Cognitive Limitations, 41 UCLA L. Rev. 1193 (1994) (discussing the unrealistic expectation in tort law that people will read, understand, and adhere to product warnings).

37 See infra note 67.

38 See, e.g., Charles A. Reich, Individual Rights and Social Welfare: The Emerging Legal Issues, 74 Yale L.J. 1245 (1965); Charles A. Reich, The New Property, 73 Yale L.J. 733 (1964).

3942 U.S.C. $\$ 607$ (1988 \& Supp. V 1993) creates the rather limited ADFC-U program covering certain unemployed parents.

4026 U.S.C. \& 32 (1988 \& Supp. V 1993).

41 See generally Anne L. Alstott, The Earned Income Tax Credit and the Limitations of Tax-Based Welfare Reform, 108 Harv. L. Rev. 533 (1995) (discussing, in part, the Earned Income Tax Credit as a politically acceptable alternative to traditional welfare programs that had not provided for the working poor).

42 See generally Stephen D. Sugarman, Children's Benefits in Social Security, 65 Cornell L. Rev. 836 (1980) (discussing the historical development of Social Security benefits). 
the Social Security program provides insurance against at least two major risks that a family's breadwinner runs: death and disability. Moreover, the benefits are administered in a reasonably dignified manner, engendering in recipients the feeling that these are "entitlements" to which they are really entitled.

Like conservatives, liberals are also frustrated with the current child support enforcement system. Yet, the absence of a mechamism better than AFDC to assure child support when the father cannot or will not pay is a far greater concern. I return to just such a mechanism below.

\section{Are Liberals and Conservatives Finding New COMMON GROUND?}

Given these two contrasting visions of family duties and the proper role of government, it is not surprising that the system our country employs at present is a compromise of both visions that is satisfactory to neitler. In AFDC, liberals achieved a cash transfer program, but not the one they wanted; conservatives liad to settle for a program they would like to do entirely without. In the last three years, however, both Republicans and Democrats have talked about welfare reform in a way that suggests a satisfying new liberal-conservative consensus miglit be achieved by casting the issues in a different way. Unfortunately, on closer inspection, a true consensus is unlikely to occur, despite slogans now in the forefront of political debate. At the moment, conservatives might have the political power to impose at least some of their vision on the nation, but this is hardly the sanie as a satisfying consensus.

\section{A. The Evil of Long-Term Dependency}

National political leaders from both parties, policy analysts, columnists, and others now agree that there is something very wrong witl "long-term dependency." Although most of the families that ever receive AFDC assistance are not dependent on the program for long periods of time, a majority of those receiving AFDC at any given point in time is $m$ the midst of what will be a long spell of welfare dependency (though perhaps interspersed with periods of 
self-sufficiency). ${ }^{43}$ Hence, a major share of the AFDC budget goes to those families.

Identifying the precise objection here is problematic, however. Obviously, there is nothing wrong per se with long-term child dependents. Indeed, in higher-income families, children are likely to continue in school and remain dependent on their parents for quite some time. So, too, long-term financial dependency of wives on their husbands fails to present a social problem in and of itself - at least so long as the couple has together decided upon this division of labor. ${ }^{44}$ To be sure, many liberal feminists object in principle to gendered social roles in which woinen become homemakers and men breadwinners, perhaps as much a result of cultural forces as any clear clioice by the couple. ${ }^{45}$ Nevertheless, neither conservatives nor liberals today show an interest in using the law to further discourage this sort of long-term dependency-as might be evidenced, for example, by efforts to eliminate joint-return filing of incoine taxes, which clearly benefits couples with highly uneven earnings. Nor does one now hear about reform efforts to eliminate dependent-spouse benefits under Social Security, which decidedly favor the retired couple witli only one wage earner. ${ }^{46}$ There are, of

43 See Mary Jo Bane \& David T. Ellwood, Welfare Realities: From Rhetoric to Reform 28-66 (1994) (discussing available data on periods and length of welfare dependency).

44 To be sure, in these days of easy and frequent divorce, a spouse may be ill-advised to agree to such an arrangement. Indeed, some features of current law seem designed to at least somewhat discourage this sort of long-term dependency. For example, the sweeping adoption in the 1970s of no-fault divorce (most strongly supported by liberals) is often associated with unfavorable spousal support outcomes from the perspective of the longterm dependent spouse. See generally Marsha Garrison, The Economics of Divorce: Changing Rules, Changing Results, in Divorce Reform at the Crossroads, supra note 22, at 75 (critiquing the argument that no-fault divorce led to the worsened financial situation of divorced women). Even under the old fault-based divorce law, however, regardless of what seemed formally promised, few divorced wives with long marriages obtained any significant amount of alimony or a property settlement at the time of divorce. See generally Stephen D. Sugarman, Dividing Financial Interests on Divorce, in Divorce Reform at the Crossroads, supra note 22, at 130 (arguing that women are no worse financially under no-fault divorce laws that under the older divorce laws). Of course, in older days divorce was much less frequent.

45 See generally Herma H. Kay, Beyond No-Fault: New Directions in Divorce Reform, in Divorce Reform at the Crossroads, supra note 22, at 6 (arguing that divorce law ought to be reformed to remove the presumptions of traditional gender roles).

46 See generally Grace Ganz Blumberg, Adult Derivative Benefits in Social Security, 32 Stan. L. Rev. 233 (1980) (discussing the advantages of Social Security benefits to single earner couples and families). 
course, those who believe that at least some of the children of the well-to-do (i.e., the idle rich who never have to work) are encouraged to lead a dissolute life by relying on their wealth. But where are the proclamations that this long-term dependency on inherited wealth is a social problem that government should remedy? Even those who maintain that all individuals have a moral obligation to "contribute" to society by working do not suggest that government should actually take steps to enforce such an obhgation against those people. Although that norm nominally governed in the Soviet Union, it is certainly not endorsed nowadays. So, too, there seems to be no moral shortcoming for a young widow and her child(ren) to be financially dependent upon the life insurance proceeds and other assets left by her deceased husband-even if this dependency continues throughout the child's minority. In short, the objection is apparently not to long-term dependency im general but rather, to dependency upon the state.

Some argue that this particular sort of financial dependency saps a single mother's initiative and sets a bad exainple for her children, teaching them to be irresponsible later in their own lives. This argument is puzzling for two reasons. First, since both conservatives and liberals these days generally endorse the idea that individuals usually know what is best for themselves, it is somewhat incongruous to argue that society ought to end this dependency in order to inake the dependents better off. To sustain the argument requires an assumption about the economic irrationality of the poor that, for conservatives at least, is at odds with much of the rest of the vision I earher set out. To escape this dilemma, it seems to me that conservatives would have to invoke the metaphor of addiction when talking about cash transfers to the poor.

Second, this argument against dependency fails im other contexts. Does anyone really think that children learn irresponsibility when their mother provides for their well-being with hife insurance proceeds froin a deceased father? Does any one object to efforts by life insurance agents to sell breadwinners sufficient coverage to inake this very dependency possible? If so, they are keeping awfully quiet about it.

Moreover, dependency on public funds does not seem to be the precise problem after all. Let us again focus our attention on that portion of the existing Social Security system, mentioned above, 
that provides wage replacement benefits for surviving spouses and children of deceased workers and for spouses and children of disabled workers (in addition to benefits paid to the disabled worker). ${ }^{47}$ This program has no noticeable opponents, liberal or conservative, apart from those who would privatize Social Security altogether and whose objections are therefore not directed towards any particular aspect of the program. Yet, under Social Security, if a man dies with a one-year-old child, his widow could be dependent upon the federal government for 15 years and the child for 17 years. On the rare occasion that a policymaker pays attention to this fact, the typical response seems to be that this system is good because it permits survivors to lead a dignified life without being. forced to accept welfare payments.

From the conservative vision I have set forth above, support for (even acquiescence in) this aspect of Social Security is initially puzzling. After all, there would be no need for Social Security benefits if parents acted responsibly and bought life and disability insurance. Some miglit argue that conservatives just got stuck with such coverage for children and their caretakers because it was pushed through Congress by liberals during the New Deal Era. Although benefits for survivor children and their inothers were established in 1939 over some Republican objection, ${ }^{48}$ they were extended to disabled children and their mothers during the conservative Eisenhower years. ${ }^{49}$ Moreover, throughout the Nixon-Ford-ReaganBush presidencies, rolling back Social Security benefits was decidedly not on the Republican agenda. Nor can conservative acceptance of Social Security children's benefits be explamed on the ground that this expenditure is very small compared to, say, AFDC. Social Security now pays out around $\$ 14$ billion annually to more than three million children and around 600,000 caretaker beneficiaries. ${ }^{50}$ Although this may seem trivial given Social Secur-

47 For a comprehensive discussion of Social Security and children's benefits, see generally Sugarman, supra note 42 , at $837-87$ (examining the history and rationale for Social Security dependents' benefits).

48 Id. at 865-66.

49 Id. at 875.

50 Stephen D. Sugarman, Reforming Welfare Through Social Security, 26 U. Mich. J.L. Ref. 817, 819-20 (1993). 
ity expenditures as a whole (including retirement benefits), ${ }^{51} \$ 14$ billion is nevertheless a hefty sum when coinpared to the approximately $\$ 25$ billion cost of the AFDC program overall..$^{52}$ Although AFDC serves more children (around nine million) ${ }^{53}$ than Social Security, the Social Security children's benefits plan nonetheless is not puny.

Of course, soine might argue that long-term dependency on Social Security is fundainentally different froin long-term dependency on welfare because deceased and disabled workers pay for this insurance through their Social Security taxes. This, however, is essentially a myth. After all, single workers and workers with either no children or grown children pay the same rates as do those with young children, and no special part of the tax is earmarked for this family benefit. In short, everyone who works, regardless whether they need this insurance, is compelled to pay for it, just as all workers are compelled to pay the regular income, property and sales taxes that fund AFDC.

A more convincing explanation for the broad ideological support for Social Security child benefits may be that it reflects a shared understanding among hberals and conservatives that, even though workers might well have individually provided for their families through life and disability insurance, mandating basic survivor and disability benefits through Social Security is a good way of forcing them to do what they should do. Furthermore, since nearly everyone might at sometime becoine a parent of a minor child, requiring all workers to contribute to this system regularly is, in a broad sense, soinething that inost workers would be willing to do if they understood their moral obligations and how the Social Security systein functions.

Still, if conservatives support a role for the state in collectively assuring that children of workers have life and disability insurance

51 In 1992, retirement and survivor benefits together amounted to more than $\$ 250$ billion, and disability benefits added to that amount more than $\$ 30$ billion. Soc. Security Admin., U.S. Dep't of Health \& Human Servs., Social Security Bulletin: Annual Statistical Supplement 1993, at 157 tbl. 4.A4.

52 Staff of House Comm. on Ways \& Means, 103d Cong., 2d. Sess., Overview of Entitlement Programs: 1994 Green Book 325 tbl. 10-1 (1994) [hereinafter 1994 Green Book].

53 Id. at 399 tbl. 10-26. 
protection, why not provide them with child support insurance as well? Moreover, if welfare dependents and Social Security dependents are in some respects distinguishable, we are still left wondering what is wrong with long-term dependency on public welfare. After all, dairy farmers, defense contractors and the like are also continually dependent on the government. Of course, in the conservative vision sketched earher, there is no place for welfare. Hence, at that extreme, any dependency on welfare (even shortterm) is wrong - though that lime of attack is obviously not one in which liberals would join.

Thus, we return full circle to a question alluded to earlier in this Article: what is the conservative response when, despite their moral aspirations for people, they are confronted with the reality that many parents have no means to support their children absent some form of public intervention? One response is to deny that reality, believing that if welfare were simply abolished, needy children would disappear as well. ${ }^{54}$ How could this happen? The conservative answer is threefold. First, fewer children would be born. Second, so long as society provides free public education through high school and free or nearly free higher education through public institutions, many inore able-bodied parents would enter the paid labor force in order to earn enough to provide a decent standard of living for their children. Third, family members and private charity would care for those few who were still in need. ${ }^{55}$

Most political neutrals examining the evidence would conclude that this response is a fantasy. Although there would undoubtedly be some movement in the directions suggested, large numbers of children would endure even harsher poverty than they do today. There are simply not enough jobs available for every needy poor single inother. Moreover, all too many of these inothers are longterm dependents with little education and few job skills; as a result, they are readily out-competed for jobs. Moreover, the unskilled jobs they might possibly obtain pay little and offer meager employee benefits. Thus, wages could not readily lift these inothers and their children out of poverty. Their relatives are also

54 See, e.g., Murray, supra note 30, at 227-29 (arguing that scrapping the entire welfare and income support system would improve the lives of large numbers of poor people).

55 Absent parents might even voluntarily pay additional child support, since without welfare, it would make a real financial difference to their children. 
unlikely to be of much assistance, as they, too, are frequently poor. Thus, the burden placed on private charity would be overwhelming. In the end, homelessness would undoubtedly rise, with some families hiving in temporary shelters and others on the street.

Given that scenario, a majority of conservatives might conclude that government should provide some assistance to children after all. Yet, it might still rankle them to give the mothers of these children a long-term "handout" from the rest of society. What annoys them is that so many Americans work and pay taxes, while welfare allows mothers who are physically capable of working to get something for nothing. Thus, unlike the defense contractors and dairy farmers mentioned earlier, long-term welfare mothers fail to "contribute" to society, and that makes them unworthy of public assistance. This attitude is bolstered by the fact that, in recent decades, women have entered the paid labor force in much greater numbers. ${ }^{56}$

Indeed, the clear message that both Republicans and President Clinton now appear to be sending is that long-term welfare dependency is wrong primarily because society provides cash to recipients who could be, but are not, performing work outside the household. Whether the Clinton position is truly liberal is a matter for later contemplation; the basic poimt for now is only that longterm dependency itself is not really the problem.

\section{B. The Push to Make the Poor Work}

Should we force poor, unemployed parents, especially simgle mothers with children im their care, to work? Is giving able-bodied poor parents a paying job, instead of cash, something both liberals and conservatives could embrace? Although the current political climate suggests yes, grave difficulties confront this solution. First, it is difficult to reconcile this proposal with Social Security's treatment of single mothers, many of whom are poor and might be on AFDC were Social Security benefits not available to them. Social Security imposes no work requirement on widowed mothers, just as none is imposed on the young widowed mothers living on private life insurance proceeds. Thus, the question is a simple one:

56 Bane \& Ellwood, supra note 43 at 67,86 . On the other hand, married women with young children work surprisingly little. 
Why should more be demanded of single mothers when the fathers of their children do not die, but just fail to pay adequate child support?

Many women who obtain Social Security survivor benefits for themselves and their children probably combine both paid employment and public benefits. ${ }^{57}$ By contrast, very few AFDC recipients combine benefits with work, or at least acknowledge doing so. In 1992 , only $4.2 \%$ of AFDC recipients reported having a full-time job, and just $2.2 \%$ reported working part-time. ${ }^{58}$ Importantly, this distinction is attributable to the AFDC program design itself. Under the Social Security rules, a surviving widowed mother can earn approximately $\$ 600$ a month before losing any of her Social Security benefits; after that, she loses benefits at a rate of $\$ 1$ for every $\$ 2$ earned, although her children's benefits continue unreduced regardless how much she earns. ${ }^{59}$ Together, these rules seem reasonably geared to the inother who works part-time for modest wages (and hence keeps almost all of her Social Security benefits) and to the one who returns to work full-time (and probably does not need Social Security for self-support).

By contrast, under AFDC, after the first four months on the program, the family benefit unit is docked $\$ 1$ of benefits for every $\$ 1$ of reported earnings ${ }^{60}$-rendering paid employment economically irrational for anyone who carmot earn enough to achieve financial independence. A few women do seem to take low-paid jobs that are of no immediate financial benefit in hopes that they will lead to better paying work in the future. Even jobs that pay more, however, may not make mothers better off if they do not replace the publicly-funded health care benefits women lose when they exit AFDC, as well as the child-care expenses incurred once mothers are no longer taking care of their children at home. Thus, for large proportions of AFDC mothers, freeing themselves from welfare dependency is a very difficult task to accoinplish.

57 Although this appears to be the general perception, I have never seen research that addresses the question.

581994 Green Book, supra note 52, at 402 tbl. 10-27.

59 Sugarman, supra note 50 , at 818-19.

60 Id. at 822 nn. $33-35$ (citing 42 U.S.C. $\$ 602(a)(8)(A)$, (8)(B)(ii)(I) (1988 \& Supp. IV 1992)). 
Oddly enough, the harsh work disincentive of AFDC was created by Republicans under the leadership of President Reagan. Although AFDC has never been as generous in this regard as Social Security, recipients used to be able to keep a third of their earnings, plus the money needed to cover actual work and child care expenses. ${ }^{61}$ Apparently concluding (contrary to the usual conservative assumptions) that this benefit structure did not provide a significant work incentive, the Republicans opted to save money and to deal with the work issue exclusively through coercion. Given AFDC's current incentive structure, it would be bizarre to conclude that mothers are morally irresponsible for refusing to combine work with welfare.

Furthermore, providing the poor with a job is much more complicated than writing them a check. Who will employ long-term welfare recipients who have been unsuccessful in the job market historically? One possibility is that poor single mothers would simply replace others who now hold jobs, such as singles, second earners, and childless married people. How might this come about? The two basic options are incentives and quotas, although both Republicans and Democrats would likely oppose these solutions. The incentive option would be prohibitively expensive because large subsidies would have to be paid before employers would prefer to hire two or three million AFDC mothers when other, more desirable workers are available. The quota option, by comparison, would interfere with the labor market and private business decisions, while unleashing opponents of "affirmative action." In either case, a different group of three milhon bitter people would be pushed out of work, many of them probably for quite soine time-a result unlikely to win favor with either. the labor movement or those who fund our unemployment compensation programs.

Thus, reformers are compelled to try other tactics to get poor parents jobs. One idea is job training, including training poor people to present themselves to employers more effectively. The notion here seems to be that while public schools may have failed to make these people competitive in the labor market early on, some extra effort can compensate for the deficiency. Ideally, pref-

61 See 42 U.S.C. $\S 602(a)(8)(A)(i v)$ (now limited by $\S 602(a)(8)(B)(i i)(I)$ ). 
erential treatment and public subsidies would be unnecessary, for these individuals would ultimately be able to earn a place in the work force on their own.

The problem with this approach is that it has not been successful; nor is it likely to be in the future. ${ }^{62}$ Cheap intervention approaches of this sort primarily place those who would have found jobs on their own even without the aid and thus make virtually no headway for those likely to be long-term welfare dependents. Intensive intervention, however, is truly expensive. Moreover, since such a large share of long-term dependents have low educational attaininent, ${ }^{63}$ even costly intervention in the form of education and training is unlikely to inake these claimants competitive for jobs that would relieve their poverty.

The next solution, therefore, is to create new jobs, often in the nonprofit and government sectors, and simply award these to welfare recipients. Conceivably, these jobs would be the next jobs employers would create if they had inore revenue; hence, by creating and filling these positions, we may even be maximizing productivity for the hiring agency. In practice, this solution is hardly feasible, if for no other reason than that those placed in the jobs would probably lack the skills to do what the agency would want froin its next hires if it were free to fill the positions on its own. In any event, this approach, too, is costly. To make the jobs pay enough to keep jobholders out of poverty after paying for child care, health care and other work-related expenses, the program would be extremely expensive-not only because that package is inuch inore exorbitant than the cost of cash payinents and health care provided to the poor today, but also because administering such a scheme would cost a great deal, as recent studies have shown. ${ }^{64}$

62 See Theresa Funiciello, Tyranny of Kindness: Dismantling the Welfare System to End Poverty in America 287, 316 (1993).

63 In 1992, of those AFDC mothers on whom educational attaininent information was available, approximately $40 \%$ were not high school graduates. 1994 Green Book, supra note 52, at 401 tbl. 10-27.

64 See Peter Passell, Economic Scene: Getting Welfare Recipients into Jobs Probably Won't Be Cheap, N.Y. Times, June 16, 1994, at D2. See also The Threat to Welfare Reform, N.Y. Times, May 2, 1994, at A16 (arguing that prior job placement and training efforts have failed because of insufficient funding). 
For this reason, the bipartisan welfare reform effort launched in 1988 has largely failed. ${ }^{65}$ At the time, the effort seened to represent a consensus annong Republicans and Democrats, demanding work froin AFDC recipients with children as young as age one. The cost of implementing the work requirement agreed upon is so large, however, that neither party in Congress has been willing to appropriate the necessary funds to put the plan into action. Hence, the 1988 law is largely einpty rhetoric in practice. For a time, some welfare critics appeared to be placated by politicians' promises to help (indeed, require) the poor to work in decent jobs. Soon, however, even those who were originally mollified saw through the formal statutory language to the absence of a viable work program for the poor.

A still different tactic is to insist on "make-work," or the requirement that AFDC recipients perform physical labor. That labor might have some productive value to an employer and might possibly build work skills in the worker, but these would essentially be side benefits. The main point is that AFDC recipients would not be idle. Thus, the poor would "contribute" by working off their welfare, so many hours a week at the minimum wage until their weekly welfare check was "earned." Although this scheme would also entail some administrative costs, the costs would be considerably less than those in the alternatives described above.

Although soine conservatives have favored this approach, liberals have traditionally abhorred it, viewing it as a punishment for being poor. Moreover, as advocates for the poor have long recognized, many poor people would inevitably fail to conform to the prograin's coercive requirements. ${ }^{66}$ For example, they would miss appointments, arrive late, and perform unsatisfactorily. As a result, they would be "sanctioned," which ineans that they would be cut off froin assistance eventually. Though such sanctions lower program costs, they do so at the expense of harming innocent children.

Another problem for liberals is that the make-work strategy does nothing to lift people out of poverty, since despite their work

65 See Bane \& Ellwood, supra note 43, at 25-26 (attributing the 1988 Family Support Act's low participation rates to lack of adequate funding).

66 See Mark Greenberg, Center for Law \& Soc. Pol'y, Understanding the Clinton Bill: Two Years and Work, July 12, 1994, at 13-15. 
program participants still end up with only inadequate AFDC benefit levels. Indeed, this solution inay inake the poor worse off if child care and other work-related expenses incurred in performing make-work are not adequately coinpensated for.

This is not to say that welfare recipients today are discouraged from working altogether. Christopher Jencks and Kathryn Edin have argued that the low levels of welfare currently provided, coinbined with work-discouraging AFDC rules, create an irresistible incentive for many recipients to cheat the systein by failing to report their other sources of incoine. ${ }^{67}$ In other words, to avoid grinding poverty, homelessness or worse, the current systein inevitably drives the needy illegally to underreport income-a significant share of which reflects under-the-table earned income from jobs whose cash compensation goes undetected by government agencies. Of course, a mandatory, government-supervised makework prograin, by occupying a substantive annount of a participant's time, would largely preclude a claimant's ability to secretly supplement AFDC. For strong behevers in law and order, this is probably a desirable outcome; even inost liberals frown upon welfare fraud. For the children of AFDC recipients who illegally supplement their income, however, the result would be detrinental.

It is interesting to note again how this problem is largely avoided under Social Security. Until Social Security recipients earn more than $\$ 600$ a month, they are not improperly receiving any public benefits. As a result, Social Security beneficiaries are rarely forced to take undesirable or illegal "cash only" jobs in order to hide their incoine, unlike inost AFDC "cheaters."

From the beginning of his presidential campaign, President Chinton has promised to restructure the current welfare system, in part by limiting the amount of time a family may receive assistance. ${ }^{68}$ As it turns out, Clinton's pledge became a proposal to provide welfare recipients witli two years of cash assistance, after wlich addi-

67 Kathryn Edin \& Christopher Jencks, Reforming Welfare, in Rethinking Social Policy 204 (Christopher Jencks ed., 1992).

68 See generally Jeffrey L. Katz, Long-Awaited Welfare Proposal Would Make Gradual Changes, Cong. Q., June 18, 1994, at 1622 (reviewing Clinton's proposal to require welfare recipients to work after receiving two years of cash assistance). 
tional assistance could only be attained by working. ${ }^{69}$ The plan would provide a job for all participants (a key point), ideally one that would pay enough to pull the job-holder off welfare and perhaps out of poverty. As previously discussed, and now clear to Clinton's advisors, this solution might be twice as expensive for the government to administer as the cash it now provides for "free."

It is unclear whether Clinton's proposal can be described as liberal. After all, the government could instead offer jobs to AFDC recipients on a voluntary basis. If those jobs were appealing, recipients would accept thein; if instead they were demeaning and pointless, yielding no possibility of improvement in material standard of hiving, no one would want them, and they would flunk the "inarket" test. Thus, for Clinton's proposal to impose these jobs regardless of their merit would seemingly turn them into punishment im liberal eyes. ${ }^{70}$ In any event, for reasons already explained, conserv-

69 For early discussion (from various political perspectives) of the Clinton plan that was introduced in the summer of 1994, see, e.g., Center on Soc. Welfare Pol'y \& L., The Administration's Welfare Reform Proposal-Two Years and What?, July 21, 1994; Jason DeParle, From Pledge to Plan: The Campaign to End Welfare, N.Y. Times, July 15, 1994, at A1, A18; Mickey Kaus, Cynics' Lesson: Reading the Fine Print of Clinton's Welfare Plan, New Republic, Aug. 8, 1994, at 6; Robert Rector, How Clinton's Bill Extends Welfare As We Know It, Heritage Found. Rep., Aug. 1, 1994, at Issue Bull. No. 200; Lies, Damned Lies, and Welfare Reform, Nat'l Rev., July 11, 1994, at 14.

70 The so-called liberal alternative to the Clinton welfare plan was introduced into Congress in the summer of 1994 by Congressman Robert Matsui. See New Player in the Welfare Game, N.Y. Times, July 18, 1994, at A14 (comparing Matsui's proposal to Clinton's plan). Congressional testimony from liberal groups criticizing the Clinton bill and generally supporting the Matsui alternative was offered, among otlers, by the National Women's Law Center (Nancy Duff Campbell), the Children's Defense Fund (Clifford M. Johnson), the American Civil Liberties Union (Deborah Lewis), the Center for Law and Social Policy (Mark Greenberg), the Clild Welfare League of America (Bruce W. Hershfield), and the Food Research and Action Center (Edward M. Cooney). See Welfare Revision: Hearing on the Child Support Provisions of H.R. 4605 Before the Subcomm. on Human Resources of the House Comm. on Ways and Means, 103d Cong., 2d Sess. 95-109 (1994) (testimony of Nancy Duff Campbell); Welfare Reform Revision: Limiting Cash Payments: Hearing on Time Limiting Cash Assistance Before the Subcomm. on Human Resources of the House Comm. on Ways and Means, 103d Cong., 2d Sess. $27-34$ (1994) (testimony of Clifford M. Johnson); Welfare Reform Revision: Limiting Cash Payments: Hearing on the Civil Liberties Implications of H.R. 46050 Before the Subcomm. on Human Resources of the House Comm. on Ways and Means, 103d Cong., 2d Sess. 35-43 (1994) (testimony of Deborah Lewis); Welfare Reform Revision: Limiting Cash Payments: Hearing Before the Subcomm. on Human Resources of the House Comm. on Ways and Means, 103d Cong., 2d Sess. 16-26 (1994) (testimony of Mark Greenberg); Welfare Changes on Child Care Providers: Hearing on Child Care and Welfare Reform Before the Subcomm. on Human Resources of the House Comm. on Educ. and Labor, 103d Cong., 
atives seem unwilling to accept the financial ramifications of Clmton's proposal, so there exists little room for common liberal/ conservative ground here.

It is fascinating that Republicans and Democrats alike have now targeted work requirement reforms towards AFDC mothers. As noted above, from the time AFDC was enacted in 1935 to the time King $v$. Smith was decided in 1968, welfare mothers were expected, or at least entitled, to stay at home and to care for their children. Although the modest work-incentive provisions earlier described had recently been adopted by the late 1960 s, no federal work requirements existed at that time (although some states imposed work requirements of their own).$^{71}$ The Nixon years, however, brought the first of an increasingly demanding set of federal requireinents whicli compelled states to someliow get women off welfare and onto someone else's payroll. Initially, welfare mothers with children six years and older were targeted,72 over time, however, it became considered and expected for a woman to work as soon as lier child reached the age of one. ${ }^{73}$ In practice, these programs accomplished little, primarily reaching only those women who volunteered for them and were "work-ready." The programs made virtually no headway witli the long-term dependents whose failure to work angers society the inost. ${ }^{74}$

One would think conservatives in favor of state-compelled work would prefer to target the absent fathers of children on welfare. By failing to fulfill their child support obligations, surely these men

2d. Sess. 9-15 (1994) (testimony of Bruce W. Hershfield); Welfare Changes on Child Care Providers: Hearing on the Impact of Welfare Reform on the Availability of Quality Child Care Before the Subcomm. on Human Resources of the House Comm. on Educ. and Labor, 103d Cong., 2d Sess. 3-8 (1994) (testimony of Edward M. Cooney).

71 See New York State Dep't of Soc. Servs. v. Dublino, 413 U.S. 405 (1973) (conisidering work rules of New York).

72 Act of Dec. 28,1971 , Pub. L. 92-223, § 3(a)(2), 85 Stat. 802,803 , codified at 42 U.S.C. $\S 602(\mathrm{a})(19)(\mathrm{A})(\mathrm{v})(1976)$.

73 Family Support Act of 1988, Pub. L. 100-485 § 201(a), 102 Stat. 2343, 2356-57, codified at 42 U.S.C. $\$ 602$ (a)(19)(C)(iii) (1988 ed. Supp. V 1993) (requiring caretakers of children over three to work up to 20 hours a week if the state provides for child care, and giving states option to impose this requirement on caretakers of children over one year old).

74 See generally Robert $\mathrm{H}$. Haveman \& John Karl Scholz, Institution for Research on Poverty, The Clinton Welfare Plan: Will It End Poverty as We Know It?, Discussion Paper July 1994 (proposing a new jobs tax credit as an alternative strategy to welfare work requirements). 
are morally at fault under the conservative vision. By contrast, while some AFDC mothers might have acted irresponsibly from the conservative perspective, a large proportion surely have not; many of these women are simply victims of bad luck, having had relationships with men who turned out to be abusers, philanderers or abandoners. If these absent fathers could be identified and put to work, a substantial share could be extracted from their wages to support their estranged children and their mothers. In turn, once single parent families received the child support payments to which they are entitled, they would then be able to work without fearing the $100 \%$ implicit tax rate now confronting AFDC recipients who supplement their income. As a result, employment among the needy would surely rise, and those now working secretly on the side would no longer be committing welfare fraud.

Interestingly enough, the idea of directing the work requirement at men has been supported in a fairly recent report from a commission headed by Michael Novak, ${ }^{75}$ but so far it seeins to have won no other substantial support. This may be because liberals have approached AFDC work requirements as though they were supposed to provide real opportunities for self-betterment. If that were actually the case, it would be understandable for AFDC jobs programs to be directed towards the relatively more deserving single mother, although, as already noted, it would still be unclear why the scheines should be coercive rather than voluntary.

Paul Offner, a member of Senator Damiel Moynihan's staff, has recently suggested a new solution to the work requirement problem. ${ }^{76}$ As I interpret his idea, the welfare mother would be given a choice. She could take the welfare job offer if she wanted it, giving her, in effect, a right of first acceptance where the opportumities are genuinely appealing. But if she did not take the job (and has established the identity of the father of her child), the father would be forced to take it instead (assuming, of course, he is not otherwise working and meeting his child support obligations). Offner illustrates his proposal with the following example: a full-time, minimuin wage job would pay an estranged father $\$ 731$ a month. In Ohio, for example, $\$ 341$ of that suin would be extracted to replace

75 Michael Novak, The New Consensus on Family and Welfare (1987).

76 See Paul Offner, Welfare Dads, New Republic, Feb. 13, 1995, at 14. 
the AFDC benefits that the man's child and the child's mother are now receiving, leaving the man with $\$ 390$ for himself. ${ }^{77}$ Some mothers would prefer the child support to the welfare job, especially if they could find a similar job on their own and keep both the $\$ 341$ and the wages (or perhaps coinbine part-time work with the \$341). It would also be cheaper for the state if the man, rather than the woman, took the job, because the state would otherwise have to pay for child care expenses as well. Presuinably, few men would voluntarily embrace Offner's scheme, because $\$ 390$ a month for full-time work is barely more than $\$ 2$ an hour; but they might be forced to participate. Still, it remams extremely doubtful that Republicans would be willing to spend the money necessary to create enough full-time minimum wage jobs for all nonsupporting fathers of AFDC recipients to fill. Republicans seem to prefer incentives that operate in a far more stark way: by cutting off welfare after two years or so, they would make the poor find their own jobs. ${ }^{78}$ That, of course, is not the solution liberals would endorse.

\section{Federalism}

With Republican victories in the 1994 congressional elections, President Clinton's welfare reform proposal has all but disappeared from public view. Instead, the center of attention, for the inoinent at least, is the Republican effort to return responsibility for welfare to the states. ${ }^{79}$ President Clinton, as a former governor,

77 Id.

78 See Center on Soc. Welfare Pol'y \& L., Welfare Reform(?) News, Ways and Means Committee Backs Block Grants March 1995 (discussing proposals permanently to deny claimants benefits from public assistance after 60 months).

79 Ending single-parent-family rights to welfare and converting federal aid to the poor into block grants paid to the states is the core of $\mathrm{HR} 4$, the Republican sponsored welfare reform bill, embraced as part of the Contract With America and passed by the House of Representatives in March 1995. See Jeffrey L. Katz, House Passes Welfare Bill; Senate Likely to Alter It, Cong. Q., Mar. 25, 1995, at 872. For more details on the plan, see Jeffrey L. Katz, GOP Moderates Central To Welfare Overhaul, Cong. Q., Mar. 18, 1995, at 813-18. For further arguments in favor of local solutions, see James Q. Wilson, A New Approach to Welfare Reform: Humility, Wall St. J., Dec. 29, 1994, at A10. For congressional testimony for and against the block grant approach, see Federal Document Clearing House, Capitol Hill Hearing Testimony (Feb. 2, 1995), available in LEXIS, Legislative Library, Congressional Testinnony File (before the Subcomm. on Human Resources of the House Comm. on Ways and Means: testimony of: Harold R. Acres, Chairman, Welfare Reform Task Force of the United Way of America; David Baker, Director, Public Div., Serv. Employees Int'I Union, AFL-CIO; Peter J. Ferrara, Senior Fellow, Nat'l Center for Policy 
also favors giving the states more responsibility for the welfare program. As the Supreme Court noted in King v. Smith, AFDC is already a scheine of "cooperative federalisin";80 this would reinain unclianged by the Republican plan. The federal government would continue to provide cash for states to help the poor, although soinewhat less than the amount Congress currently provides. The plan would also free states from a long list of federal minimum requirements now imposed as a pre-condition for receiving federal grants-including, perhaps inost centrally, the current obligation of states to provide aid to all single parent families who meet the federal test for eligibility. ${ }^{81}$ Thus, Alabama could presumably resurrect the provisions declared invalid in King $v$. Smith, although constitutional restraints would obviously still apply. ${ }^{82}$ As a further exainple, states could also, if they wished, cut aid to AFDC recipients entirely if they refused to accept low inconie housing in lowcost rural areas.

This proposal would also prohibit the states from providing aid to certain groups targeted by conservatives, such as teen mothers and children born to AFDC recipients. ${ }^{83}$ Although this aspect of the proposal is ideologically incongruous with the notion of federalism, the conservative distaste for aid to these groups is strong enough to overlook the inconsistency. The devolution strategy also rids Republicans of the work requirement issue (and its attendant cost), leaving it to the states to handle as they wish. So far, state legislatures, too, appear reluctant to spend the large sums needed to make work requireinents effective. ${ }^{84}$ Freed from the federal

Analysis; Clifford M. Johnson, Director, Children's Defense Fund; Katherine McFate, Assoc. Dir. of Research for Soc. Policy, Joint Center for Pol. and Econ. Studies); Federal Document Clearing House, Capitol Hill Hearing Testimony (Feb. 2, 1995), available in LEXIS, Legislative Library, Congressional Testimony File (before the Senate Budget Comm.: statement of Sen. Pete V. Domemici; testimony of Gov. John Engler (MI)).

80 King, 392 U.S. at 316.

81 See 42 U.S.C. $\$ 602(a)(10)$.

82 For discussions of early federal efforts to combat state efforts to impose unconstitutional conditions on their AFDC programs, see Winifred Bell, Aid to Dependent Children (1965); Note, Welfare's “Condition X," 76 Yale L.J. 1222 (1967).

83 Both restrictions are contained in HR 4, the welfare reform bill passed by the House of Representatives in March 1995. See generally Katz, House Passes Welfare Bill, supra note 79 (discussing the proposal and its chances for success).

84 See Mickey Kaus, Workfare Wimp-Out, New Republic, Mar. 13, 1995, at 4. 
"entitlement" bind, states may be able to fend off local opposition to welfare in other ways, without insisting on workfare.

To be sure, without a federal structure to bind them, liberal states could, in theory, adopt entirely new regimes free from the shortcomings of the current AFDC system. In practice, however, the prospects for this sort of reform are nil. Although little evidence supports the proposition that needy people will move to the states providing the most generous welfare benefits, ${ }^{85}$ many take this proposition on faith to be true. This fear, for example, explaims why the Republican reform plan clearly authorizes states to provide lower benefits to newcomers. ${ }^{86}$ In the face of enormous fears (valid or not) that certam states will be flooded with welfare recipients, it would be a bold move for a state to enact a liberal solution to -poverty while its neighboring states, provided with less federal funding, were reducing the welfare assistance they provided. As a result, this new federalism will probably not provide a cominon ground on which conservatives and liberals will meet. ${ }^{87}$

\section{Taking Children Away From Their Parents}

Lately we have also heard a lot about orphanages, not.from liberals, but from Charles Murray, today's welfare guru of the Right, and our new Speaker of the House, Newt Gimgrich. ${ }^{88}$ Perhaps the orphanage is best understood as an alternative to a job or cash assistance. That is, if poor people have children they cannot afford to raise, the child is placed in an institution for its own protection.

85 See Miclrael Wald, Stanford Center for the Study of Families, Cliildren, and Youth, Welfare Reform and Children's Well-Being, Sept. 1, 1992, at 30.

86 See Katz, GOP Moderates Central to Welfare Overhaul, supra note 79, at 816.

87 For a discussion of President Clinton's objections to the Republican bill that passed the House, see Robert Pear, Clinton Objects to Key Elements of Welfare Bill, N.Y. Times, Mar. 26, 1995, at A1.

88 See Clrarles Murray, The Coming White Underclass, Wall St. J., Oct. 29, 1993, at A14. See also Myron Magnet, Problem No. 1: The Children, N.Y. Times, Nov. 25, 1994, at A37 (calling for the establishment of community hostels for needy children and their mothers and arguing that, if the mothers do not want to live in sucls places but cannot support their children, the children should be taken away and placed in foster homes far from the neighborhoods in which they were born); Robert Rector, Combatting Family Disintegration, Crime, and Dependence: Welfare Reform and Beyond, Heritage Found. Rep., Apr. 8, 1994, at Backgrounder No. 983 (arguing that federal aid currently given to unwed mothers should be converted to block grants and given to the states to promote orphanages and adoption). 
In the orphanage, some conservatives claim to have found a solution to the dilemma described earlier: paying cash promotes the wrong behavior; providing jobs is too expensive; and doing nothing results in child misery and homelessness. If the innocent child can be well provided for, perhaps the system can be humanitarian without creating perverse incentives.

There is some reason to doubt that the orphanage proposal is seriously envisioned as a method of dealing with children whose mothers are thrown into poverty through divorce. ${ }^{89}$ But children of unmarried women are a mucli more inviting conservative target, especially if they are born to teenage motliers. Indeed, wlien the focus is restricted to teenage mothers (especially young teens who should be in school), even liberals must strain to maintain their first principle. Although they believe all women should be able to raise a child umimpoverished, where does it say that such an entitlement should be available at any age? The image of clildren raising children is one that liberals are not eager to embrace. Moreover, turning to the second liberal principle, perhaps putting children of teenage motliers in orphanages strikes many as a way of actually improving the lives of newborn children.

As an institutional solution, orphanages are liardly new. Rather, they reflect a return swing of the pendulum away from what traditionally has been called "outdoor" relief (casli) and back once more to "indoor" relief (describing not only the orphanage, but also the "poorhouse," where poor mothers typically joined their children, and the "workhouse," where poor fatliers lived as well). ${ }^{90}$ Oddly enough, a revolt agamst these very imstitutional arrangements yielded the precursor to AFDC-tlie "motliers' pension" movement that was formed in $1909 .^{91}$

89 One newly emerging response to that reality is fathers' groups who argue that the man should gain custody of the children, if he wants them, when the alternative is that the mother and the children would have to rely on welfare to survive. See generally Thom Weidlich, Dads' Rights Advocates Come of Age, Nat'l L.J., Mar. 13, 1995, at A1 (discussing rise of father activists movement).

90 See Michael B. Katz, In the Shadow of the Poorhouse: A Social History of Welfare in America (1986) (discussing the "poorhouse" era, when institutions were the preferred response to extreme poverty); Michael B. Katz, The Undeserving Poor: From the War on Poverty to the War on Welfare (1989).

91 For a description of the history of the mothers' pension movement, see Committee On Economic Security, Social Security in America: The Factual Background of the Social 
In the end, Murray and other conservatives probably do not anticipate creating a mammoth orphanage bureaucracy with masses of children under its supervision. The cost of full-time institutional support for a child would be fabulously large as compared with the money now spent on that child under AFDC. Instead, it seems that Murray and others are relymg on a series of behavioral responses that would make the orphanage option a rarely used last resort: if impoverished women knew they could not keep a child they could not support, they would respond by getting pregnant less frequently, opting for abortions more frequently, and giving up more children for adoption. ${ }^{92}$ Under this scenario, it is possible that the few children who did go to orphanages would be benefitted by doing so (imagme a mother whose constant drug usage renders her incapable of providing for her child). Liberals, of course, would find this solution harsh, especially for more mature mothers who reasonably (or perhaps only somewhat unrealistically) hope they will find a way to provide for their children, but fail. If a woman is so eager to be a mother, should she still lose her child?

In any event, the behavioral responses so far imagined only present part of the story. Although abortions and adoptions would probably rise and pregnancies fall (just as would occur if welfare were simply eliminated), many pregnant single women would probably continue their pregnancy, praying for the best. Perhaps the father will come through; if not, perhaps family members will do what is required. Indeed, many family members probably would pitch in, preventing the need for many of these mothers to surrender their children to orphanages. This does not mean, however, that such children will have escaped poverty. To the contrary, forcing more families to double up would presumably drag down even more children; the price of impoverishing their own children to spare a new single mother the loss of her child is one some relatives would reluctantly pay. This is hardly good for children, and we

Security Act as Summarized from Staff Reports to the Committee on Economic Security 233-250 (1937); Linda Gordon, Pitied But Not Entitled: Single Mothers and the History of Welfare, 1890-1935, at 37-66 (1994); Joel F. Handler, Reforming the Poor: Welfare Policy, Federalism, and Morality 11-16 (1972).

92 Ironically, the Republican proposal to curtail aid to teen mothers has elicited fierce opposition from right-to-life supporters because of the likely increase in abortion that would result from the proposal. See Mickey Kaus, Life Rift, New Republic, Feb. 13, 1995, at 6 . 
already know what it leads to in the urban Third World: armies of child beggars.

In sum, I thus far fail to see how a satisfactory liberal-conservative consensus can be achieved under the banner of long-term dependency, required work, federalism, or orphanages.

\section{Child Support Assurance Instead?}

Revisiting the discussion up to this point, there appear to be only two areas of real overlap between liberals and conservatives concerning the functions of government with respect to the financial support of children. First, there is general agreement on the desirability of an active state role in the imposition and collection of child support in settings where parents live apart because they are either divorced or were never married to each other. Second, there is general support for Social Security child and caretaker benefits where the breadwinner parent is deceased or disabled. In this Part I explore whether this accord might be extended to include an expanded role for Social Security in providing financial support for children with an "absent" parent.

When Social Security child benefits were first introduced in 1939 , the main category of AFDC recipients at that time were widowed mothers and their children. ${ }^{93}$ The clear goal of the reformers was to move the lion's share of these claimants off one program and onto the other, and they have largely succeeded. Today, nearly two million children witl a deceased parent receive Social Security benefits, and fewer than 200,000 such children are on AFDC. ${ }^{94}$ At the end of the 1950s, when Social Security benefits for disabled workers were adopted, the provision of additional benefits for those workers' children represented a second important step in the same direction, once more moving families off AFDC and onto Social Security. This aspiration too has largely been attained. ${ }^{95}$ Indeed, at that time there were many who envisioned a gradual withering of AFDC because families of "deceased" and "incapaci-

93 Stephen D. Sugarman, Roe v. Norton: Coerced Maternal Cooperation, in Robert H. Mnookin, In the Interest of Children 371 (1985).

941994 Green Book, supra note 52, at tbls. 1-15, 10-26 \& 10-27 (indicating that just $1.6 \%$ of the nearly 9 million children receiving AFDC had a deceased parent).

95 Only $4.1 \%$ of children received AFDC in 1992 because of the incapacity of a parent. Id. at tbl. 10-27. 
tated" fathers would receive more favored Social Security treatment. But these visionaries did not reckon with the coming explosion in both marital dissolution and child-bearing outside of marriage. Divorced and never-married cases, which comprised a tiny share of the AFDC load in the 1930s, overwhelmingly dominate the plan today. ${ }^{96}$ Is it now time for a third step? In short, just as Social Security now provides children with life imsurance and disability insurance, should it also deliver what would, in effect, be child support insurance?

\section{A. Child Support Assurance In General}

In recent years, others liave proposed, in varying forms, a completely separate, new "child support assurance" prograin. ${ }^{97}$ Representatives from both political parties liave provided early backing for Irwin Garfinkel's plan, the scheme that has been discussed most extensively. ${ }^{98}$ In its widest formulation, child support assurance would guarantee any single parent a specified level of child support regardless whether that amount of money were actually obtained from the absent parent. The guarantor, of course, would be tlie government.

96 More than $83 \%$ of children were on AFDC for one of these two reasons in 1992. Id.

97 For earlier proposals in a somewhat similar vein, see President's Commission on Income Maintenance Programs, Background Papers 442-45 (1970); Chambers, supra note 20, at 265-68; Alvin L. Schorr, Poor Kids 112 (1966); Alvin L. Schorr, Welfare Reform and Social Insurance, Challenge, Nov./Dec. 1977, at 14. In her recent book Theresa Funiciello discusses expanding the social security approach as a way to solve the welfare problem, but ultimately suggests a broader scheme that would provide nonstigmatizing benefits to all single parent families. Funiciello, supra note 62, at 297-304. For a different wrinklecalling for the provision of "individual development accounts" for the poor-see Michael Sherraden, Assets and the Poor: A New American Welfare Policy 220 (1991). For yet another new strategy-relying on "loans"-see Lee Anne Fennell, Interdependence and Choice in Distributive Justice: The Welfare Conundrum, 1994 Wis. L. Rev. 235, 325.

98 For descriptions and discussions of Garfinkel's plan, see Irwin Garfinkel, Assuring Child Support (1992) [hereinafter Garfinkel, Assuring Child Support]; Institute for Research on Poverty Study, Child Support Assurance: Design Issues, Expected Impacts, and Political Barriers as Seen from Wisconsin (Irwin Garfinkel, Sara S. McLanahan \& Philip K. Robins eds., 1992); Irwin Garfinkel, Daniel R. Meyer \& Gary D. Sandefur, The Effects of Alternative Child Support Systems on Blacks, Hispanics, and Non-Hispanic Whites, 66 Soc. Serv. Rev. 505 (1992). On the political front, see Downey-Hyde Child Support Enforcement and Assurance Proposal: Hearings Before the Subcomm. on Human Resources of the House Comm. on Ways and Means, 102d Cong., 2d Sess. 1 (1992) and the more recently introduced "Secure Assurance for Families Everywhere (SAFE) Act," H.R. 4051, 103d Cong., 2d Sess. (1994) (introduced by Democratic Rep. Woolsey of California). 
Garfinkel's proposition should be distinguished from children's allowance schemes of the sort that exist in many countries and are proposed as an American solution by some advocates. ${ }^{99}$ First, whereas children's allowances are typically paid across the board to all parents, Garfinkel's plan focuses solely on single-parent households. Second, the child support assurance approach promises only a guarantee which the absent parent must reimburse to the extent of his child support obligation. The children's allowance, by contrast, is unconditional and would be supplemented by the full extent of child support payments from absent parents. Although some hiberals would undoubtedly prefer a generous children's allowance, Garfinkel's plan has captured the attention of politicians and analysts because, by being far more closely tailored to need, it would be much less expensive.

Probably the most critical question in child support assurance plans is the level of the guarantee. It could be the poverty level or greater, which would, of course, make the proposal most appealing to liberals. In practice, most of the discuission so far seems to envision a somewhat lower sum (on cost grounds). ${ }^{100}$ Still, a single parent could try to escape poverty by earning wages on top of the guaranteed support ainount. Under most versions, she could keep all outside earnings (or, under some proposals, she would have to give back only a sinall proportion of the support guarantee, such as fifteen or twenty cents per dollar earned). The upshot is that it would make good economic sense to combine work and the child support guarantee in ways that combining work and welfare currently does not.

Although Garfinkel and his supporters have not wanted to characterize it this way, the child support assurance plan is essentially a reformed AFDC scheine. The guarantee is equivalent to a new AFDC benefit level. And the new "implicit tax" rule is the equivalent of reducing AFDC's implicit marginal tax rate froin

99 Children's allowance schemes exist in nearly all other industrialized nations, although the value of the benefit varies widely. Our existing tax deduction for families with children is a poor substitute because it actually provides a larger benefit to higher income parents. The 1994 Republican Contract With America proposal that a $\$ 500$ tax credit be permitted for each child continues this regressive feature because the proposal benefits only those who pay taxes.

100 See Garfinkel, Assuring Child Support, supra note 98. 
$100 \%$ to zero (or perhaps to fifteen or twenty percent). To the extent that child support assurance would be provided to a single parent regardless of her wealth, the plan essentially ends AFDC's "assets test" which now bars claimants from the program who have anything more than a minimal amount of liquid assets. ${ }^{101}$

Calling this reform assured child support may carry a cosmetic advantage (the advantage of nonstigmatization) for both the claimants and withm the political process. Indeed, that may be the greatest attraction of the reform. This approach would lead to cost increases, however, at least as great as would parallel changes in AFDC parameters. To be sure, the plan anticipates the collection of as much of the support guarantee as can be fairly and practically extracted from the child's absent parent. Of course, this is what Congress increasingly is trymg to do with the AFDC child support enforcement program.

Therefore, although this proposal ought to garner significant support among hiberals, conservatives can be expected to make their usual objections. Put differently, in order to make any headway with conservatives, I believe that the child support assurance scheme must narrow its focus so as to target only a portion of smgle mothers. A possible limit might be that the mother can only qualify for the plan if she names the father of her child and cooperates in effectively establishing his paternity. This, of course, is already a supposed requirement in AFDC (absent a narrow "good cause" excuse, such as "he will beat me up if I tell"). ${ }^{102}$ In practice, however, a substantial portion of fathers remain unidentified even when AFDC recipients do not receive formal good-cause exceptions. If actually establishing patermity rather than merely cooperating were made an entrance requirement in the new child support assurance schenie, paternity would be verified at a higher rate than in AFDC today. Nevertheless, this limit would still permit into the program teen parents and others targeted by conservatives, an out-

101 See 42 U.S.C. $\$ 602$ (a)(7)(B) (1988) (limiting AFDC recipients essentially to $\$ 1,000$ in liquid assets, a home, and a modest automobile). How child support assurance would treat recipients' other sources of income is another question not always adequately addressed in the proposals to date.

10242 U.S.C. $\$ 602(a)(26)(B)$ (1988); see generally Sugarman, supra note 93 (discussing government efforts to enlist mothers to secure child support from fathers). 
come that would likely prevent any substantial conservative endorsement.

\section{B. Child Support Assurance Through Social Security}

I propose a different sort of child support assurance, one that would cover children of "absent" parents under Social Security. ${ }^{103}$ More precisely, I argue that we should entitle a child and his or her caretaker parent to the same Social Security benefits when the caretaker is a single parent owing to absence as they would have obtained if single parenthood had arisen from the death of the other parent.

Paying the child support assurance under Social Security's existing rules would have several consequences that might gather conservative support without sacrificing liberal backing. First, ehgibility would, by its nature, require proof of paternity in order to determine on whose Social Security account the benefit claim could be made. Thus, this plan would exclude mothers who, in conservative eyes, are too irresponsible to know and to demonstrate who the father is or are improperly unwilling to name the father in order to relieve him from his child support obligation. ${ }^{104}$

Second, this plan may diffuse somewhat the heated controversy over paying out extra money for children born after the mother is on AFDC. For one thing, to the extent that the conservative objection to such payments rests on the idea that the rest of us should not have to pay for large welfare families, Social Security already contains an important constraint. Its "family maximuin" provision typically means that no extra benefits are provided after the second child (or after the third if the caretaker is working full-time) ${ }^{105}$ Admittedly, this maximum applies per father, not per inother, so that a woman with children froin several men would not be limited in the way someone with many children from the saine man would be. Still, this provision does put a cap on the benefits payable on

103 For a more detailed version of the proposal, see Sugarman, supra note 50 .

104 There admittedly remains the woman who, for example, has good reason to fear physical violence from the man and reasonably believes that police and other public officials will be unable to protect her from that risk. Conservatives in particular are loath to allow these men to avoid paying child support; I acknowledge, however, that they represent a real dilemma for my proposal.

10542 U.S.C. $\$ 403(\mathrm{a})(1988)$. 
any one man's account. Moreover, the conservative objection to paying aid to "after-borns" may lose a fair amount of its sting when raised in the Social Security context. Social Security already pays extra benefits for children of disabled workers born long after the worker has become disabled. ${ }^{106}$ At that point Social Security clearly is not serving an insurance function; rather it is responding to the needs of children. So, too, of course, that is why liberals object to recommendations to deny AFDC to children born after their mother is on the program.

Third, because the existing Social Security benefit formula would apply, this plan would mute the political controversy over setting the support level. Rather than providing a uniform support guarantee, as other child support assurance plans envision, this plan bases benefits on the past wages of the absent parent. It thereby serves what many would consider the desirable function of relating the level of assistance to the child's past standard of living. ${ }^{107}$ Indeed, the Social Security benefit formula nicely mirrors the traditional practice of awarding private child support. The critically important consequence is that a substantial fraction of recipient families would be boosted out of poverty through the payment of the Social Security benefit alone. ${ }^{108}$

Fourth, many young mothers, especially teen mothers, would be unable to claim these new Social Security benefits for themselves and their children. This is because the fathers of those children would be much less likely to be "insured" for Social Security purposes. ${ }^{109}$ Although many liberals might wince at the exclusion of some poor mothers, it is probably essential for conservative support. Moreover, there is a possible silver lining here. Once we

106 Jimenez v. Weinberger, 417 U.S. 628, 634-35 (1974).

107 Although the Social Security benefit formula is wage related, it is structured to replace a larger proportion of the wages of lower earners and in this respect should appeal to liberals.

108 See John R. Kearney, Herman F. Grundmann, \& Salvatore J. Gallicchio, The Influence of Social Security Benefits and SSI Payments on the Poverty Status of Children, 57 Soc. Sec. Bull. 27, 28 (Summer 1994) (noting that the proportion of single parent families above the poverty line that receive OASDI benefits is greater than the proportion of similar families in the general population).

109 To be eligible for death benefits today, the worker on whose account the benefit is claimed must generally be "currently insured," which requires having earned a sufficient level of covered wages in six of the last 13 quarters prior to the person's death or qualification for old age benefits. 42 U.S.C. $\S 414(\mathrm{~b})(1988)$. 
move a significant share of current AFDC recipients onto Social Security, AFDC would become a much smaller program and, as such, a less appealing target for those who are prone to bash the poor. Furthermore, although younger women remaining on AFDC and most at risk of long-term dependency may receive even worse treatment than they receive today, that need not be the case. Rather, by restricting AFDC, society could focus on other social intervention strategies that are too daunting today when they must fulfill the needs of so many recipients. I return to these possibilities at the conclusion of my discussion.

This assumes, of course, that liberals and conservatives can be convinced that single-parent families should receive Social Security because the child's other parent is absent. Let me return then to the basic existing difference between Social Security family benefit recipients and AFDC recipients: whereas the women on the Social Security sclieme are mostly widows and wives of disabled men, the women on AFDC are mostly divorced from or were never married to the fathers of their children.

In seeking conservative support, it is important to consider divorced mothers separately from unmarried mothers. As noted earlier, it is very difficult for conservatives to maintain that most divorced women are at fault for their single-parent status. After all, inany of these women have been abandoned by their husbands or have left them for very good reasons, such as to escape doinestic violence. To claim that these woinen are to blame because they irresponsibly married and had children with these unreliable men clearly sounds preposterous in a great many, even if not all, cases. Moreover, although many of these women might remarry to improve their family's financial position, outsiders are hard pressed to argue that it is immoral not to have done so when ordinarily they cannot appraise the suitability of any potential new husband. ${ }^{110}$ Furthermore, it is important to underscore that, under Social Security rules, reinarriage would automatically terminate the caretaker parent's benefit, although not the child's. ${ }^{111}$

110 In any event, the same argument could be made regarding widowed mothers on Social Security; their benefits, however, are paid so long as they remain unmarried.

11142 U.S.C. $\$ 402$ (g)(1) (1988). 
Finally, candor requires conservatives to admit that restricting the divorced woman's remedy to her private child support awardeven with governmental aid in the collection process-will leave considerable child poverty. The problem, plainly, is that all too many inen, by conservative values, simply fail to live up to their moral obligations. No amount of plausible government enforcement activity shows much promise of collecting all that would be needed to prevent many children from remaining poor.

Should society do more for these children and their mothers? It seems that, once conservatives have accepted Social Security protection for other children, children of divorced parents have a very powerful argument on "equal treatment" grounds. Simply put, our society is willing to provide long term Social Security benefits to survivor children because we know that some fathers will irresponsibly fail to purchase life insurance. Similarly, we ought to be willing to provide a parallel form of child support insurance when we know that some fathers will divorce their wives and irresponsibly fail to pay the support they owe. In short, thinking about this from the child benefit side, and appreciating the Social Security limitations already discussed as part of the package, this is an idea that many conservatives ought to endorse.

Once we turn away from divorced women to single, unmarried mothers, it will be far more difficult to win conservative support. Undoubtedly, conservatives will be quick to see most of these women as irresponsible, even if their children are innocent and in need. Nonetheless, the existing Social Security scheme may provide a good basis for compromise. If current policy were extended to cover absent-parent cases, divorced families would receive both caretaker parent benefits and children's benefits. Conversely, only children's benefits would be paid to families whose mother and father had never been married. The U.S. Supreme Court upheld this type of discrimination in Califano v. Boles. ${ }^{112}$ Although I personally find that decision unfair (and illogically argued for reasons not worth pursuing at this time), for my purposes here this distinction might suffice to gain conservative sponsorship.

112443 U.S. 282 (1979) (holding that children's benefits would be paid to illegitimate children, but caretaker benefits would not be paid to women who were never married to the deceased father of the child). 
So far I have been discussing my proposal from the benefit side. Now it is time to address its fundmg. One option would be to finance this new benefit just as we fund the other Social Security children's benefits - through uniform payroll taxes. Although I do not think this would be the likely outcome, it deserves brief attention nonetheless.

It is wortl considermg at the outset whether workers who might be willing to make Social Security contributions in order to provide life and disability insurance would want to pay for child support imsurance. Given the high rate of divorce in contemporary society, a large proportion of men would probably be very happy to know that, if they divorce from their wives and do not take custody of their children, those children's financial well-being will be reasonably taken care of by Social Security. To be sure, some men would oppose having to buy this imsurance because they do not have young children and cannot imagine getting divorced. The opposition would probably mcrease once it was understood that the risk of fatllering a child outside of marriage is also being imsured against, albeit at a lower level. Exactly this sort of objection has been totally unavailing, lowever, agamst the survivor and disability benefits already provided by Social Security.

Thinking about the funding question from the perspective of women workers is ratlier more coinplicated. Because mothers usually wind up with primary custody of their children after a divorce or separation, ${ }^{113}$ the overwlielming proportion of women workers would know that it would be a rare occasion when their Social Security accounts would be called on to support children and fathers. This, in turn, might tempt them to oppose paying for this sort of imsurance. On reflection, however, women workers would have at least two reasons to hesitate to draw this conclusion. First, a parallel complaint could be made about today's Social Security survivor benefits for children and their caretakers. Most of the deceased workers on whose accounts these benefits are paid are men; yet women's advocates do not seem to be campaignimg to get

113 See generally, Robert H. Mnookin, Eleanor E. Maccoby, Catherine R. Albiston \& Charlene E. Depner, Private Ordering Revisited: What Custodial Arrangements are Parents Negotiating?, in Divorce Reform at the Crossroads, supra note 22, at 37 (studying divorce in two California counties and concluding that a majority of mothers obtain full custody of their children). 
rid of this benefit for that reason. Second, there may be a pragmatic explanation for this lack of opposition. In the end, perhaps women see themselves as the primary beneficiaries of Social Security child and caretaker benefits in deceased worker cases. Of course, that would also be the case under the proposed absent-parent benefit. Although the funding comes from a different category of women than those who receive the benefits, they are often the same women in dual roles-as paid workers and as mothers.

Nevertheless, even if these concerns can be overcome, an additional objection may doom conservative support for financing this proposal in the way other Social Security children's benefits are funded. Many will worry that this plan will promote marital dissolution, especially by enabling inen to walk out on their families. This is what insurance analysts term the moral hazard problemthe very availability of the insurance stimulates undesirable conduct that triggers the payment of the insurance. By contrast, hardly anyone is willing to die or to become totally disabled in order to trigger the payment of Social Security benefits to his family.

Financing the benefit in a new way overcomes this objection. Men who could afford to pay for child support would be required to reimburse Social Security for the benefits it pays, up to the level of their support obligation. In short, men would not be relieved of any of their current obligations. They would simply pay them into Social Security instead of to the child's mother or to AFDC officials as they do today. If their support obligation was greater than the Social Security benefit, they could still pay the full amount to Social Security, who would pay the excess to the child. This approach presumably would discourage men from leaving their children as much as the obligation to pay child support does now.

Whether child support enforcement through Social Security will be more, less or equally efficient as it is today is an open question I put aside here. It is worth noticing, however, that with the rapid growth in child support withholding at the source-even for noncustodial parents who are not behind in their payinents-most child support payors will not really notice whether their withheld wages go directly to their former spouse or to the Social Security Administration which credits the withheld wages against the benefits payinent made to the recipient spouse and child. Indeed, with 
more and more people receiving Social Security and other payments through electronic funds transfer mechanisms, many recipients will simply receive statements reflecting that their accounts were credited with what they are owed. For many divorced spouses, this inpersonal and automatic system should remove one conflict point from their ongoing relationship with respect to their children.

This approach to funding provides insurance on the child's side, but much less so on the worker's side. Workers would be insured only to the extent that the family benefit is larger than the support payment they are fairly asked to inake (soinething that would tend to be true the lower the worker's past earnings). With this structure, the proposal is less easily justified by appealing to the selfinterest of male workers who might want to buy child support insurance. Instead, workers must be convinced that such a plan is necessary as a way of assuring benefits to innocent and presumptively needy children.

Many mothers, it should be noted, would face different incentives than those im effect today. Under the proposed plan, if a woman divorces her child's father, her prospects of actually gaining a support payment from the government are much increased. Moreover, that payment is likely to be larger and much less stigmatizing than that received under AFDC. This could promote family dissolution initiated by woinen. Nonetheless, it is extremely awkward to object to woinen's responses to financial payinents that they currently have the legal right to receive. In other words, it is hardly seemly to relish that soine women do not end intimate relationships today because of fears that the father of their children will default on their legal and moral duty. Furthermore, as already noted, under Social Security rules, a woman who has a child without marrying the child's fatlier would receive no caretaker benefits, thereby bluntmg the risk that my proposal would promote single parenting.

Funded to the extent feasible by absent parents themselves, my proposal may appear to many simply as a revamped AFDC plan with new benefit levels, a sharply reduced work disincentive structure, and an administrative apparatus calculated to reduce beneficiary stigma for a privileged class of current AFDC recipients. Of course, I would hope that most people would laud this package as a 
considerable improvement from the current plan. The program has far greater consequences, however, than those apparent so far.

Like existing Social Security children's benefits, the proposed absent-parent benefit would not be restricted to poor families. Because Social Security contains no "assets" test, that mechanism would not exist to exclude most nonpoor families. Furthermore, unlike AFDC, Social Security is not affected by unearned income from other sources, a feature that helps concentrate AFDC on the poor. Finally, as explained earlier, when the caretaker beneficiary takes up full-time work or marries, only her Social Security benefit disappears. Her children's benefits contmue.

The outcome is that my proposal would extend the new benefit well beyond the poor to all divorced mothers who fail to receive the child support payments they are promised. In fact, surely most of the plan's payout would go to women who would never be on AFDC (although in many of these cases Social Security would simply serve as a conduit for the transfer of child support payments from the child's father to the inother). In this way, middle-class women and working-class women could become allies of poor mothers. Indeed, I believe that the best political prospects for my proposal lie in convincing all single mothers that it would well serve their interests and those of their children. ${ }^{114}$

In sum, perhaps the best prospect for attracting conservative support for a new incoine transfer program lies in subdividing the existing AFDC population. This can be done by excluding that

114 For an indication of what might be an incipient backlash against solving the welfare problem by relying on child support, see Roger J.R. Levesque, Looking to Unwed Dads to Fill the Public Purse: A Disturbing Wave in Welfare Reform, 32 U. Louisville J. Fam. Law 1 (1994) (maintaining that the current trend of using child support to solve welfare problems is based on punitive measures against unwed fathers).

As an aside, note the interesting treatment of step-relationships that would occur under my proposal. On the benefit side, if a man had children with two women and ended up living with neither, all the children would be able to claim support on an equal basis (but again limited by the family maximum cap). If a man became a stepparent to a child, that child would later be able to claim on the stepparent's account if the child's mother and stepfather separated-but only if the stepfather had become the child's principal source of support. This, however, is a less likely result than today because the child would in many cases already be assured support through the scheme on his biological father's account. Note too that there would not necessarily have to be a single principle applicable to the funding side. For example, stepfathers might not be asked to reimburse Social Security for payments made to their stepchildren after the family break-up in the way that biological fathers would be. 
portion which attracts the greatest conservative ire and identifying for better treatment through Social Security that portion which is most similar to those single parent families already covered by Social Security. Although this may not be the favored solution of liberals, liberals nonetheless ought to support the improvement it would bring in the lives of a large number of currently poor children. For liberals to oppose this reform would be like liberals calling for the elimination of existing Social Security children's benefits and the return of many of those children to the AFDC rolls.

\section{Those Left Out}

Even if a substantial share of those now on AFDC were moved to Social Security, the question remains as to what should become of those who are not. One strategy is to hope that their numbers will be relatively sinall and then to ignore thein, leaving them on AFDC and in the same position in which they now find themselves. It seems clear, however, that increased support could be won for the Social Security expansion I propose if a consensus reform could also be reached for this other group.

Although conservatives might want simply to eliminate AFDC altogether, leaving those in the remaming group to fend for themselves, including that remedy in the package is likely to force liberals to oppose the Social Security portion. Moreover, it is by no means clear that the states would welcome a simple abandonment of AFDC by Congress. Most of them have general assistance schemes in place that provide state and/or locally funded cash grants to the poor who are not supported by other programs. The first consequence of ending AFDC, then, would be to move these recipients onto the general assistance rolls, but now without any financial contribution toward their support from the federal government. Of course, states could bar former AFDC recipients from their general assistance plans; they could even eliminate their general assistance plans (although in some cases this would take a state constitutional amendinent). Still, it seems implausible that states that are willing to provide general assistance to single ablebodied males would not aid poor children. In short, for Congress merely to abandon AFDC would be "reverse revenue-sharing." 
A large share of the group that would not shift to Social Security would probably be unmarried teen mothers or former unmarried teen mothers who have long received AFDC benefits-the group that seems to vex conservatives the most. Many hiberals are also disturbed by the phenomenon of a rapid growth in the number of children born to unmarried teen mothers (especially when most of those mothers are not marrying the fathers of their children in "shotgun" weddings). As previously noted, although protection of the children of these teens is a fundamental commitment of liberals, it is unclear that the liberal first principle-to enable people to afford to raise their children-extends to minors. If nothing else, many liberals believe that when teens become simgle inothers they are likely to destroy what chances they liad for post secondary (or èven secondary) education and an opportunity to get ahead financially. What then might we do other than simply provide cash to these young women after they become mothers?

Abstractly, the sensible strategy would seen to combine two goals: discouraging unmarried teen motherhood in the first place and, when it occurs, providing assistance for the child of the teen mother in a new format. Converting these principles into an agreement is not easy, however. As usual, there are both carrot and stick approaches. As for the first goal, a typically recommended stick is simply to deny AFDC to the minor mother, ${ }^{115}$ requiring her to be supported by her own family. If her own nother is on AFDC, then the new child is added as a grandchild to the grandmother's AFDC benefit unit, a result which generally brings in a small amount of additional cash. This approach at least discourages young women from getting pregnant for the purpose of moving away froin home and using the AFDC grants to rent their own apartinents. Unfortunately, at least some young woinen who are so inotivated appear to decide on this course of action in response to violence that is directed toward them in their mother's home. ${ }^{116}$

115 For a discussion of the Clinton bill's approach to teen pregnancy, see Jodie LevinEpstein, Center for L. \& Soc. Pol'y, Teen Pregnancy Prevention and Teen Parents, July 27, 1994.

116 Mike Males, Correspondence, New Republic, Jan. 2, 1995, at 4 (letter to the editor stating that "two-thirds of teenage mothers are past victims of sexual abuses inflicted by men averaging more than 25 years old"). (Mike Males is a doctoral student in social ecology at the University of California, Irvine.) 
This sad reality has caused hberals to oppose the cut-off if no exceptions are allowed. Another stick some conservatives have advocated would force pregnant teens to leave their regular high school and attend school elsewhere. This recommendation, which cuts in exactly the opposite direction to the efforts in which liberals have been engaged over the past two decades, is premised on the idea that too many teen mothers today are seen as receiving special treatment by their peers and, as such, set very bad examples. Yet another stick entails leaning on the fathers of these children. One way, as earher discussed, would be to force the fathers to work and then to pay child support out of their earnings. ${ }^{117}$ Even if it cost inoney to create the needed jobs for this group, the hope is that the threat would discourage more of these inen from getting women pregnant. An alternative gambit would be to start enforcing the statutory rape laws-a role that prosecutors seem to have abandoned in recent times.

Liberals, not surprisingly, have tended to favor carrots. One is to provide poor teens with free contraceptives and free abortions. These measures, it is argued, at least curtail teen mothering that is not truly the young wornan's choice. Right-to-life politics has tended to keep Republicans from endorsing these ideas. A different carrot would be to bribe young women not to becoine pregnant. For example, in selected high schools, fernales could volunteer to submit to regular (say, monthly) pregnancy tests on the understanding that if they passed they would receive so inuch money each time. If the amount were large enough to make a real difference in helping them to purchase desired items (e.g., clothes or CDs), this could have an impact. Indeed, it could change high school culture regarding the desirability of pregnancy in schools where it is now a common phenomenon. It would only be costeffective, of course, if it prevented enough births that the resulting social savings would cover what inevitably would be payments to inany who would not have become mothers even without bribery. As noted earlier, conservative qualms about paying people to do the right thing might reduce support even if this tactic paid for itself, if only by the health care costs thereby saved. Furthermore,

117 See supra text accompanying notes 70-78. 
the racial politics card could well be played if it appeared that supporters were motivated by a desire to see fewer children of color. ${ }^{118}$

In these few paragraphs I concede that it is likely to be difficult to reach a consensus on what to do about teenage pregnancy, even if the phenomenon is observed with dismay by Democrats and Republicans alike. Perhaps the best hope for agreement lies in the area of greater supervision of the teen after she has become a mother. This could involve the use of representative payees who would receive the young mother's monthly benefits check and thereby control how money provided to support the child should be spent, or, more generally, to ensure intensive social worker interaction with the teen mother. ${ }^{119}$ In an earlier era, social workers were seen to be mucli more involved witl AFDC recipients. ${ }^{120}$ Both resentment at this intrusion and the explosion of the welfare rolls have all but wiped out this practice. Nonetlieless, if AFDC numbers were reduced significantly as a result of my Social Security proposal, the prospect of reintroducing social work becomes more practical. With a focus on teen mothers (rather than mature divorced women), social worker intervention miglit once again seem to be a good idea to many people across the ideological spectrum. Putting child welfare services back into AFDC just might "end welfare as we know it"-turning it from a scheme that pays out money and turns the single parent loose, into one that pays much closer attention to the welfare of the children it was originally designed to assist.

118 Some private experiments of this sort have been undertaken, for example, by Planned Parenthood and its "Dollar-a-Day Program" in Colorado. During the 1980s a scheme, involving cash payment, was organized to discourage teen mothers from having a second child. For a description of the program and the controversy surrounding it, both within and outside of Planned Parenthood, see Nancy Kates, Buying Time: The Dollar-aDay Program (case study prepared for use in the Kennedy School of Government, Harvard University 1990) (on file with the Virginia Law Review Association).

119 See generally Neil Gilbert, Welfare Justice: Restoring Social Equity 27.(1995) (outlining methods of improving parenting skills of teenage mothers).

120 See generally Joel F. Handler \& Yeheskel Hasenfeld, The Moral Construction of Poverty: Welfare Reform in America 116-21 (1991) (discussing the rise and decline of social activism). 


\section{CONCLUSION}

Although both liberals and conservatives say they want to "end welfare as we know it," because they have such divergent starting points regarding the role of government in the financial support of children the commonly proposed solutions of either side are even more unacceptable to the other side than is the current system. ${ }^{121}$ This makes welfare a continuing thorn in the side of the body politic despite its relatively trivial cost relative to the entire federal budget. I propose a compromise solution that splits today's welfare population. To simphify, woinen who now come into AFDC because of divorce (and in some cases unmarried women because of abandonment) would instead be able to turn to Social Security for themselves and their children, just as widows do. New approaches could then focus particularly on never married teen mothers, the AFDC beneficiaries who create the greatest uproar and who are now most at risk of long-term dependency on welfare. If a social consensus were reached to support this plan, an economic consensus could be achieved to support the necessary increase $\mathrm{m}$ the Social Security payroll tax, which, after all, would be substantially offset by reductions in the rest of the budget for current state and federal welfare costs.

121 For a public survey identifying problems with welfare and reforms that would find public support, see Youth Law News, Suprises [sic] in Public's View of Welfare Reform, May/June 1994, at 21-22 (reviewing results of public survey conducted in November 1993, questioning voters' criticisms of and reform proposals for the welfare system). 
HeinOnline -- 81 Va. L. Rev. 25741995 